II. I
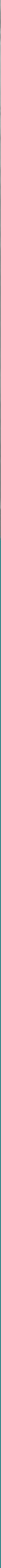

The Economic Benefits of Renewable Energy 


\section{What is Renewable Energy?}

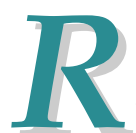

enewable energy sources are either continuously resupplied by the sun or tap inexhaustible resources, such as geothermal energy. In contrast, fossil fuels - oil, coal, and natural gas - form so slowly in comparison to our rate of energy use that we are essentially mining finite, nonrenewable resources and will eventually exhaust quality supplies.

The use of modern renewable energy technologies produces less pollution than burning fossil fuels especially with respect to net emissions of greenhouse gases. Indigenous renewable energy resources also represent a secure and stable source of energy for our country and a potential source of jobs and economic development.

Renewable energy can be used in a variety of ways. This document focuses on the use of renewables (except hydropower) to generate electricity. Renewable transportation fuels and "direct use" applications — such as water and space heating with biomass, solar, or geothermal energy; and the mechanical pumping of water with wind energy — are not addressed in this document.

In some cases, the cost of electricity produced from renewable sources is approaching the cost of generating power from conventional sources, and each renewable energy technology is economically feasible in certain applications.

\section{The Purpose of This Document}

$F$

or decades, proponents of

renewable energy technologies have focused on their indirect economic benefits, such as the reduced health and environmental restoration costs stemming from their lower environmental impact. These arguments have been acknowledged as legitimate, but have had little real effect on energy resource and policy decisions, partly because they are difficult to quantify.

This document illustrates the direct economic benefits, including job creation, of investing in renewable energy technologies. Examples are drawn from across the nation, showing the value of generating electricity from indigenous renewable resources in several regions. Each of the most promising renewable energy technologies is examined in turn, emphasizing the impact that individual projects have had on the state and the local community.

This document quotes actual employment numbers at existing facilities. Where available, total national employment for that sector of the renewables industry is also cited. There are few estimates of the potential for future job creation within any particular sector, due to the difficulty in making accurate projections. 
"The fate of people on Earth depends on whether we can employ efficient and renewable energies. We need to lay big plans for small technologies."

- David Freeman, former head of the New York Power Authority, Tennessee Valley Authority, Sacramento Municipal Utility District, and the Lower Colorado River Authority, speaking at the World Renewable Energy Congress in June 1996

Importing Energy, Exporting Jobs $\ldots \ldots \ldots \ldots \ldots 2$ Eectricity From Biomass $\ldots \ldots \ldots \ldots \ldots \ldots .4$

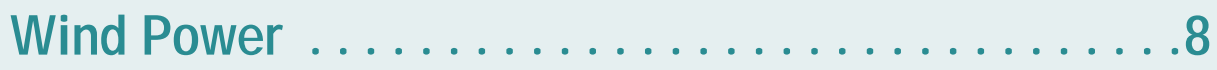

Photovoltaics: Eectricity from Sunlight . . . . . . 12 Solar Thermal Electricity: Power from the Sun's Heat . . . . . . . . . . . 16

Geothermal Energy: Power from the Earth . . . . . 18 For More Information ...............20 Glossary .........................21 


\section{Importing Energy, Exporting Jobs}

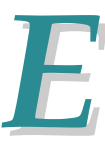
very year, Americans spend about $\$ 1900$ per person on energy purchases, which is about $8 \%$ of the average person's total expenditures on goods and services in a given year. Of this amount, approximately $40 \%$ goes to pay for electricity. Energy purchases represent a significant cost to society - nationally and locally - and it is important to spend energy dollars in a way that strengthens the economy rather than depleting it.

In many cases, energy dollars leave the community, going to regional utilities or suppliers of oil or natural gas. Once those dollars have been spent on importing energy into the community or state, they are not available to foster additional economic activity. Because every dollar spent on imports is a dollar lost from the local economy, these energy imports represent a substantial loss to local companies in terms of income and jobs. The challenge is to meet our insatiable appetite for energy while supporting local economic development.

\section{A growing number of state and local governments are investigating ways to keep their energy dollars at home - for many, the answer lies in renewable energy investments.}

\section{How Renewable Energy Investments Help the Economy}

There are two main reasons why renewable energy technologies offer an economic advantage: (1) they are laborintensive, so they generally create more jobs per dollar invested than conventional electricity generation technologies, and (2) they use primarily indigenous resources, so most of the energy dollars can be kept at home.
According to the Wisconsin Energy Bureau, "Investment in locally available renewable energy generates more jobs, greater earnings, and higher output ... than a continued reliance on imported fossil fuels. Economic impacts are maximized when an indigenous resource or technology can replace an imported fuel at a reasonable price and when a large percentage of inputs can be purchased in the state." The Bureau estimates that, overall, renewables create three times as many jobs as the same level of spending on fossil fuels.

For states and municipalities with insufficient conventional energy reserves, there is a simple trade-off: import fossil fuels from out-of-area suppliers, which means exporting energy dollars ... or develop indigenous renewable resources, which creates jobs for local workers in the construction, operation, and maintenance of nonfossil power plants and associated industries.

The advantages of renewable energy investments are becoming increasingly clear, even in areas that have traditionally favored fossil fuels. "Texas is now a net energy importer," said Texas Land Commissioner Garry Mauro, speaking at the dedication of the state's first commercial wind-power project in November 1995. "We can accept our status as a net energy importer ... or we can face the challenge head on and serve as a model to others by embracing new ideas such as wind power and solar energy - ideas that will make Texas the leader in renewable energy development, energy-efficient building techniques, job creation, and environmental health."

The renewable energy industry provides a wide range of employment opportunities, from high-tech manufacturing of photovoltaic components to maintenance jobs at wind power

\section{The Multiplier Effect: A Little Goes a Long Way}

The multiplier effect is sometimes called the ripple effect, because a single expenditure in an economy can have repercussions throughout the entire economy, much like ripples spreading across a pond. The multiplier is a measure of how much additional economic activity is gen-erated from an initial expenditure.

In the town of Osage, lowa, for example, $\$ 1.00$ spent on consumer goods in a local store generates $\$ 1.90$ of economic activity in the local economy. This occurs as the dollar is respent; the store pays its employees, who purchase more goods, all with the same original dollar.

The multiplier effect causes different types of economic benefits as a result of investments in renewable energy technologies:

Direct effects - These are on-site jobs and income created as the result of the initial investment; the people who assemble wind turbines at a manufacturing plant, for example.

Indirect effects - These are additional jobs and economic activity involved in supplying goods and services related to the primary activity; people such as the banker who provides loans to the plant's owners, and the workers who supply parts and materials to the turbine assemblers.

Induced effects - This is employment and other economic activity generated by the respending of wages earned by those directly and indirectly employed in the industry; jobs created by the manufacturing plant workers spending their wages at the local grocery store, for example. 
"A state that imports most of its fossil fuel can receive a substantial employment and earnings benefit from developing indigenous renewable resources."

- Powering the Midwest: Renewable Electricity for the Economy and the Environment, a 1993 report by the Union of Concerned Scientists

plants. Through the multiplier effect (see sidebar, left), the wages and salaries earned by industry employees generate additional income and jobs in the local economy.

The taxes paid by renewable energy companies also strengthen the area's economic base, ultimately reducing the burden on individual taxpayers in the community; in fact, generating power from renewable resources contributes more tax revenue than generating the same amount of power from conventional energy sources. As an example, the California Energy Commission has found that solar thermal power plants yield twice as much tax revenue as conventional, gas-fired plants.

In some cases, renewable energy investments can enable individuals, companies, or communities to reduce their utility bills. For example, schools can cut costs by using wind power (see page 10), and electric cooperatives can provide cheaper electricity to members with photovoltaics (see page 15).

Although the local economic benefits associated with renewable energy investments are evident, it is also important to note that, in the short term, increased reliance on in-state energy resources could reduce the income of energy-exporting states. In the long term, however, the advantages of developing renewable energy technologies go far beyond the local economy - they benefit the country as a whole. The United States leads the world in manufacturing renewable energy power systems, most of which

\section{The Lost Potential of Energy Dollars}

Several states have made efforts to quantify their electricity and total energy expenditures - a difficult task. Here are some examples of states that import energy.

- Massachusetts imports $97 \%$ of the energy it uses. In energy dollars this translated to $\$ 11$ billion in 1992 . The state imports $15 \%$ of the electricity it consumes.

- In 1990, lowa imported nearly $97 \%$ of its energy at a cost of about $\$ 5$ billion.

- Wisconsin imports $94 \%$ of its energy. In 1992, more than $\$ 6$ billion of Wisconsin's $\$ 8.1$ billion total energy bill left the state - approximately $\$ 1200$ per resident. In its 1994 study, The Economic Impacts of Renewable Energy Use in Wisconsin, the Wisconsin Energy Bureau reported that "The energy dollar drain from the state due to fossil fuel imports has hindered additional economic growth and job development."

- New York depends on out-of-state sources for nearly 92\% of its energy requirements. Each New Yorker sends an average of $\$ 1000$ each year out of state to purchase energy.

- Rhode Island imports more than $90 \%$ of its electricity from other states.

- In 1990, Missouri spent $\$ 9.7$ billion on energy, $70 \%$ of which left the state to pay for the energy. This equates to $\$ 6.8$ billion, or more than $\$ 1300$ for each Missouri resident.

- In 1992, Maine residents and businesses spent approximately \$2.8 billion on energy, \$2200 for every person in the state. Maine imports about $25 \%$ of its electricity.

- Hawail: $85 \%$ of the state's electricity is generated from imported fuel oil, compared with only $3 \%$ for the United States as a whole.

- In 1990, the 100,000 residents of the U.S. Virgin Islands spent about \$40 million on electricity, $65 \%$ of which left the Virgin Islands economy. More than \$26 million drained out of the territory's economic bucket that year for energy purchases, equivalent to about $\$ 260$ per resident.

- Minnesota imports $15 \%$ of the electricity it consumes.

- Oregon imports $11 \%$ of its electricity from other states.

- Despite extensive oil reserves, even Texas is now a net energy importer.

are exported to industrializing nations. The lack of adequate fossil-fuel reserves in many of these countries, combined with their lack of extensive electricity grids, makes renewable energy technologies an increasingly popular choice for power generation. The growing demand for electricity in developing nations can continue to create jobs for U.S. workers - as long as the United States maintains a competitive position in foreign markets by continuing to invest in renewable energy technologies at home.
"Every year, people, companies and governments in the [Midwest] region spend over $\$ 100$ billion on energy in all its forms - electricity, fuel oil, gasoline, coal and others. This amounts to about $\$ 1900$ for every adult and child, or roughly 10\% of average personal income."

- Powering the Midwest: Renewable Electricity for the Economy and the Environment, Union of Concerned Scientists, 1993 


\section{Overview}

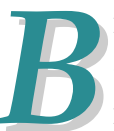

iomass is a general term for all of the Earth's plant and animal matter. In the renewable energy industry, however, biomass usually refers to: (1) energy crops grown specifically to be used as fuel, such as fast-growing trees; (2) agricultural residues and by-products, such as straw, sugarcane fiber, and rice hulls; and (3) residues from forestry, construction, and other wood-processing industries. (Note: As defined here, biomass does not include municipal solid waste or landfill gas.)

Biomass currently accounts for around $1 \%$ of total U.S. electric generating capacity, or $8 \%$ of the country's renewable-source generating capacity. In 1995, there was approximately $7700 \mathrm{MW}$ of grid-connected biomass power capacity in the United States.

According to a 1992 study by Meridian Corporation and Antares Group Inc., the biomass power generation industry employs more than 66,000 people nationwide. In 1992, the industry created more than $\$ 1.8$ billion in personal and corporate income, and generated more than $\$ 460$ million in federal and state taxes.

Because biomass power activities tend to be concentrated in rural areas, this technology offers a great opportunity for revitalizing rural America. The U.S. Department of Energy (DOE) estimates that a concerted effort to develop dedicated energy crops for biomass power plants could generate 120,000 new jobs over the next 15 years.

\section{Success Stories}

\section{Maine: Leading the Nation}

Maine obtains a greater percentage of its electricity from nonhydro renewable sources than any other state. The biomass power industry generates

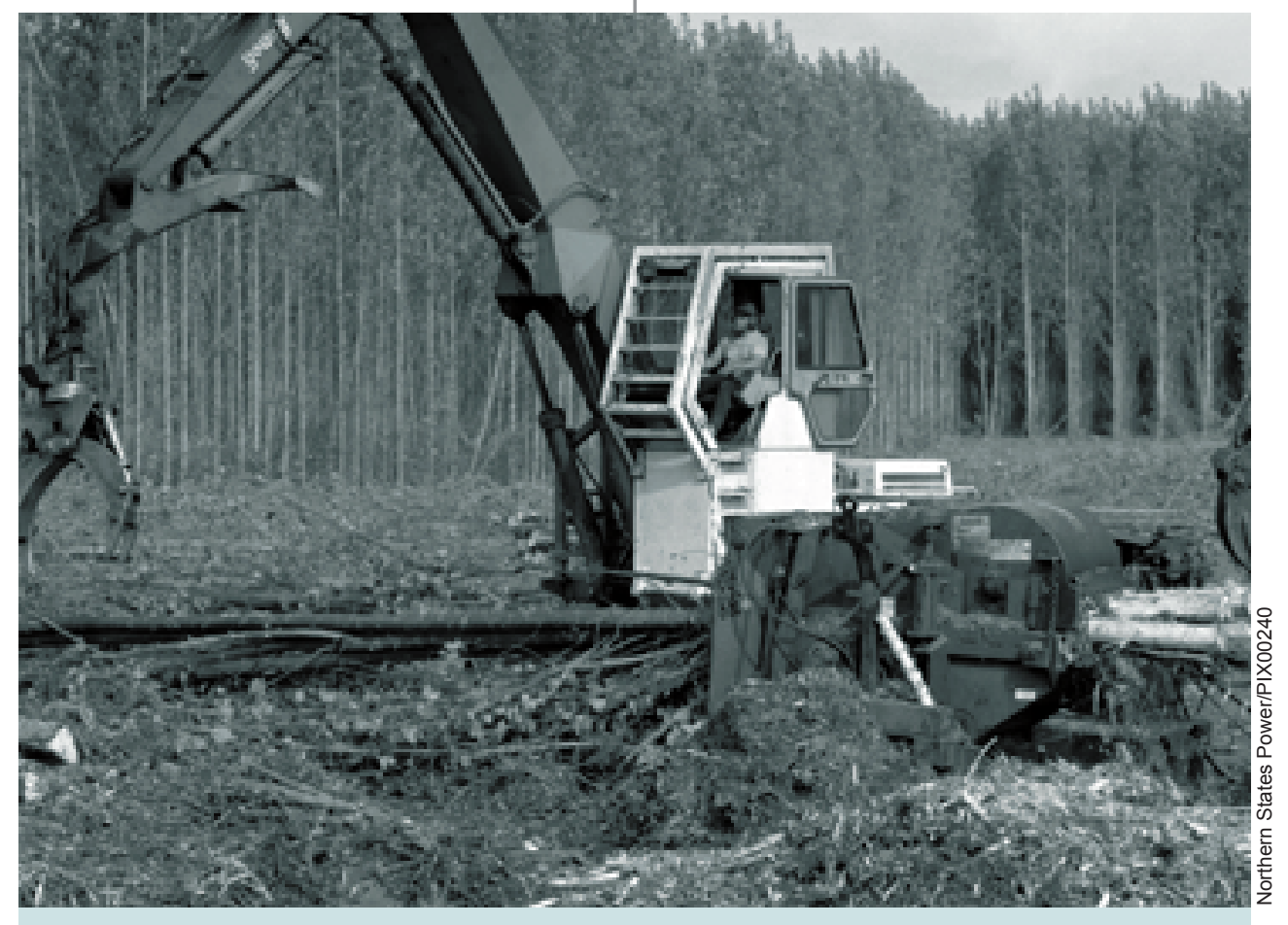

The biomass power industry creates thousands of jobs in fuel production and harvesting for rural workers, such as this grapple operator on a tree farm in Oregon.

$25 \%$ of Maine's electricity and supports 2780 jobs in wood harvesting and transport, power plant construction and operation, and associated retail and service sectors. The industry has nearly $500 \mathrm{MW}$ of installed capacity in 21 generating plants.

\section{"Small power producers ... have} been one of Maine's largest sources of new employment and investment."

- State Planning Office of Maine, quoted in Energy Choices Revisited: An Examination of the Costs and Benefits of Maine's Energy Policy, Mainewatch Institute, 1994

In rural districts with limited employment opportunities, a single power plant can have a critical impact on the local economy. This is the case with Fairfield Energy Venture, a 32-MW biomass plant located in the town of Fort Fairfield in northeastern Maine.

\section{Everyone's a Winner}

The Fairfield Energy facility provides approximately 140 jobs (38 at the plant and about 100 in wood harvesting) and more than $30 \%$ of the town's property tax base. With a population of 4000 , and only about 1270 jobs available in the area, the biomass plant is vital to the health of the town's economy. "We consider ourselves lucky to have the energy plant," acknowledged a representative of the Fort Fairfield Chamber of Commerce.

The biomass plant has generated substantial economic benefits for the local and state economies, both during initial construction and since. The facility was completed in 1988 after a two-year construction period. During this phase, the plant's developers spent more than $\$ 8$ million in the state of Maine, including $\$ 5.3$ million paid in wages to local workers for on-site assembly and construction. 
In 1992, Fairfield Energy Venture had annual operating expenses of \$12 million, \$9.4 million of which was spent in the state's economy. Of the in-state expenditures, more than $\$ 7$ million stayed in Fort Fairfield and the surrounding area. This includes $\$ 1.7$ million in wages and salaries paid to plant employees and more than $\$ 938,000$ paid to the local and state governments in property taxes, fees, and licenses.

A 1994 Mainewatch Institute study found that, "From the start of the project it appears the town and local area have been winners. Local tradespeople were employed in the on-site construction; parts and supplies were purchased from local outlets whenever possible; and the influx of engineers, consultants, and temporary out-oftown workers provided substantial benefits to local restaurants, gas stations, motels, and food stores."

Fairfield Energy Ventures is also expanding the skill base of local workers. Only one of the plant's employees had any previous experience working in a power plant. The Mainewatch Institute study quotes Peter Powers, the plant's general manager, as saying, "All but one of our employees were Maine residents prior to being hired by the plant and all live in close proximity to the plant." Seven of the employees (including the general manager) had previously worked in the navy, and were able to make use of their training in steam propulsion. Many of the plant workers were hired at entry-level positions, and the company is committed to training them to help ensure job advancement and employment stability.

\section{How It Works}

Because plants and trees use sunlight to grow, biomass energy is actually a form of stored solar energy. Biomass energy can be converted to electricity in two ways:

Direct combustion involves burning the biomass in a boiler to heat water, then running the resulting steam through a turbine - the same process used in conventional coal-fired plants. Virtually all biomass electric plants today use conventional steam turbines.

Gasification involves converting the solid biomass to a gas that is then burned in a combustion turbine - potentially much more efficient, but still in the demonstra tion stage of development.

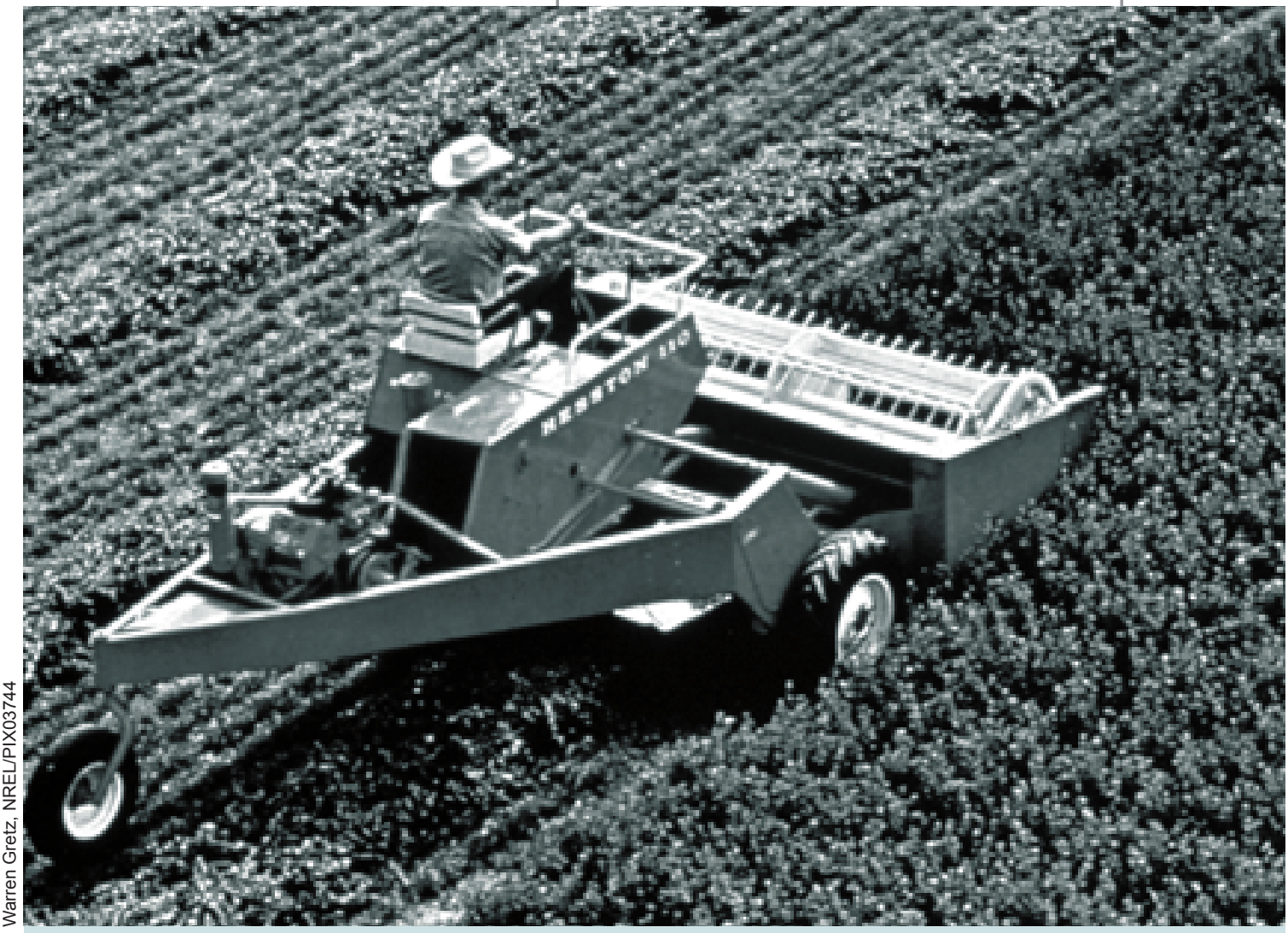

Harvesting alfalfa in Minnesota. Damaged crops can still be used as a biomass feedstock. 


\section{Income from Energy Crops}

To expand power production from biomass substantially beyond current levels will require the cultivation of dedicated energy crops. New York has become the focus for a new initiative to develop agricultural feedstocks for energy production. This should help to stabilize the revenue stream for participating farmers: 26 area farmers have expressed a desire to diversify their crop production to include energy feedstocks.

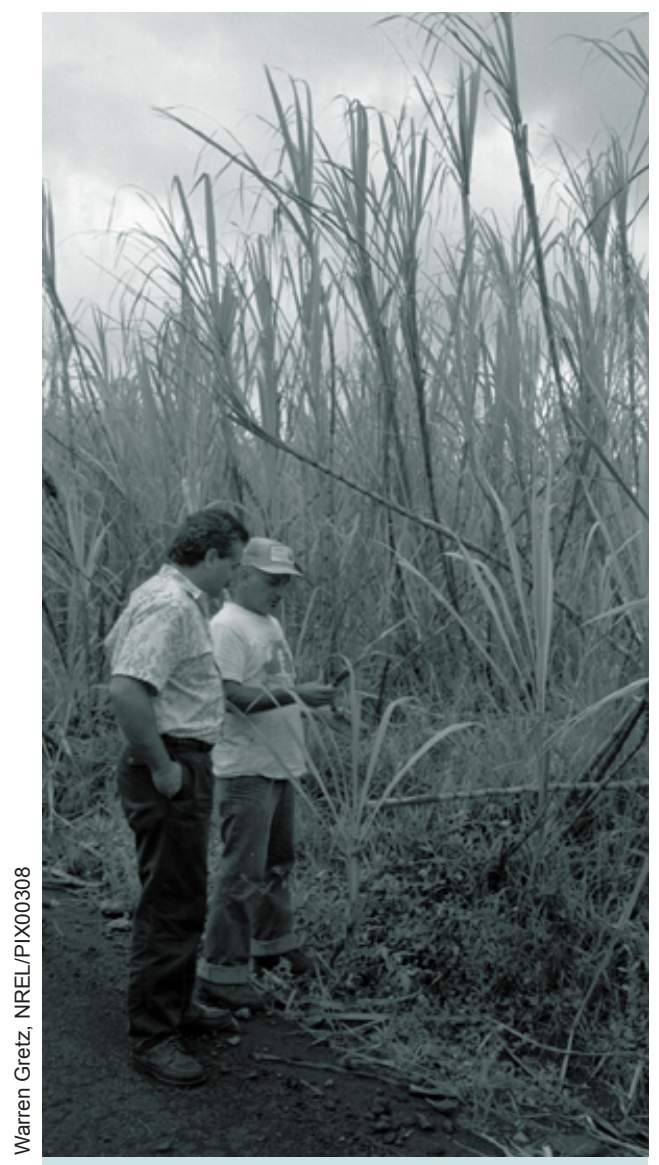

Most agricultural wastes can be used to generate electricity, including the mountains of fibrous material left over from processing sugarcane crops such as this one in Hawaii. Selling power to electric utilities helps to improve the economics of sugar production for local companies.
The Niagara Mohawk Power Corporation and the State University of New York (SUNY) are members of a consortium that is developing willow energy crops on 1000 acres of farmland around Tully, New York. This is the first stage of a plan to convert over 40,000 acres in central and western New York to growing willow trees for energy by 2010 . Once it is fully implemented, the plan is expected to create 300 rural jobs and generate energy crop fuel sales of almost $\$ 20$ million annually.

Each New Yorker sends an average of $\$ 1000$ each year out of state to purchase energy. In 1992, only one half of New York's farmers were able to earn a profit on farm operations. A "homegrown" willow crop bought by power companies will help keep energy dollars in the state and generate new income streams for farmers.

According to Dan Robison, a researcher at SUNY's Syracuse College of Forestry, "There are a lot of farmers in New York who are struggling to stay in business. There are a lot of farmers throughout the region who are essentially working for free, on a break-even basis, and any new opportunities they're interested."

Hybrid willow species are being developed by the project partners to be fast-growing and resistant to drought and disease. Male willow trees can thrive in soils and climates less suitable for other crops. These trees require minimal application of fertilizer and insecticides and will assist in the control of soil erosion. Because willow is planted once, then repeatedly harvested from the same plant for up to 20 years, soil erosion is minimized compared to traditional row crops.

"This is ... a very good alternative farm crop ... a cash crop," said Larry Abrahamson, another of SUNY's researchers.

\section{Bad Weather? Good News ...}

The agricultural community of Granite Falls, Minnesota, will soon become the home for a new 75-MW biomass gasification power plant that will be built just outside of town. The plant will employ 100 full-time staff and will create an additional 60-80 part-time jobs for people handling the biomass feedstock.

\section{"It's going to generate jobs in the community - the plant itself - but the other part of it is that it's economic development with the farmers."}

\section{- Farmer Dick Jepson, in an interview for the 1996 DOE video, Growing America's Energy: The Story of Biomass Power}

A small group of area farmers and business people are developing alfalfa as an energy crop for the power plant. Alfalfa is normally grown primarily for use as cattle feed. When bad weather destroys the crop, it can no longer be fed to cattle, but the damaged stems can still be used as a feedstock for electricity production.

"We'll have a ready market for the stems," said John Moon, a local farmer. "A brown stem has just as much quality for gasification as a nice stem that hasn't been rained on."

In good years, the alfalfa crop will be separated into stems and leaves. The leaves will be sold as cattle feed, and the stems will be sold to the biomass plant. So in addition to producing clean energy for Minnesotans, the plant provides a second source of income for area farmers.

Because biomass plants can use a wide range of organic material, the technology is suitable for generating power in virtually any agricultural region - as far east as Maine, or as far west as Hawaii. 


\section{Electricity from Sugarcane}

For a state such as Hawaii, which is currently forced to generate most of its electricity from expensive, imported fuel oil, renewable energy resources are particularly valuable. Approximately $8 \%$ of Hawaii's electrical power is already being generated from biomass, the state's largest source of renewable energy, and research is under way to make better use of this resource.

Most of Hawaii's biomass plants use bagasse, the fibrous waste from sugarcane processing. Sugar is Hawaii's most important agricultural export, and local sugar mills burn bagasse to provide thermal power to the mills and electricity for sale to utility grids. These mills use directfired steam-turbine generators.

Because biomass gasifiers are more efficient, they are potentially capable of producing $50 \%$ more electricity from the same amount of bagasse when compared with systems that burn the bagasse directly. This has prompted the State of Hawaii to explore gasification technology in partnership with DOE and an industry research group.

The government-industry joint venture has built an experimental gasification facility at the Hawaiian Commercial \& Sugar Company mill in Paia, on the island of Maui. The facility currently processes almost 100 tons of bagasse per day into biogas. Jerry Smith, the manager of the project, knows how important electricity produced from biomass is to Hawaiians.

\section{"It keeps the people on the island} working. Plus, with a plant this size, you're not dependent on importing oil. And that's a big thing when you're sitting on an island."

\footnotetext{
- Jerry Smith, Paia gasifier project manager, in a 1996 interview for Growing America's Energy: The Story of Biomass Power
}

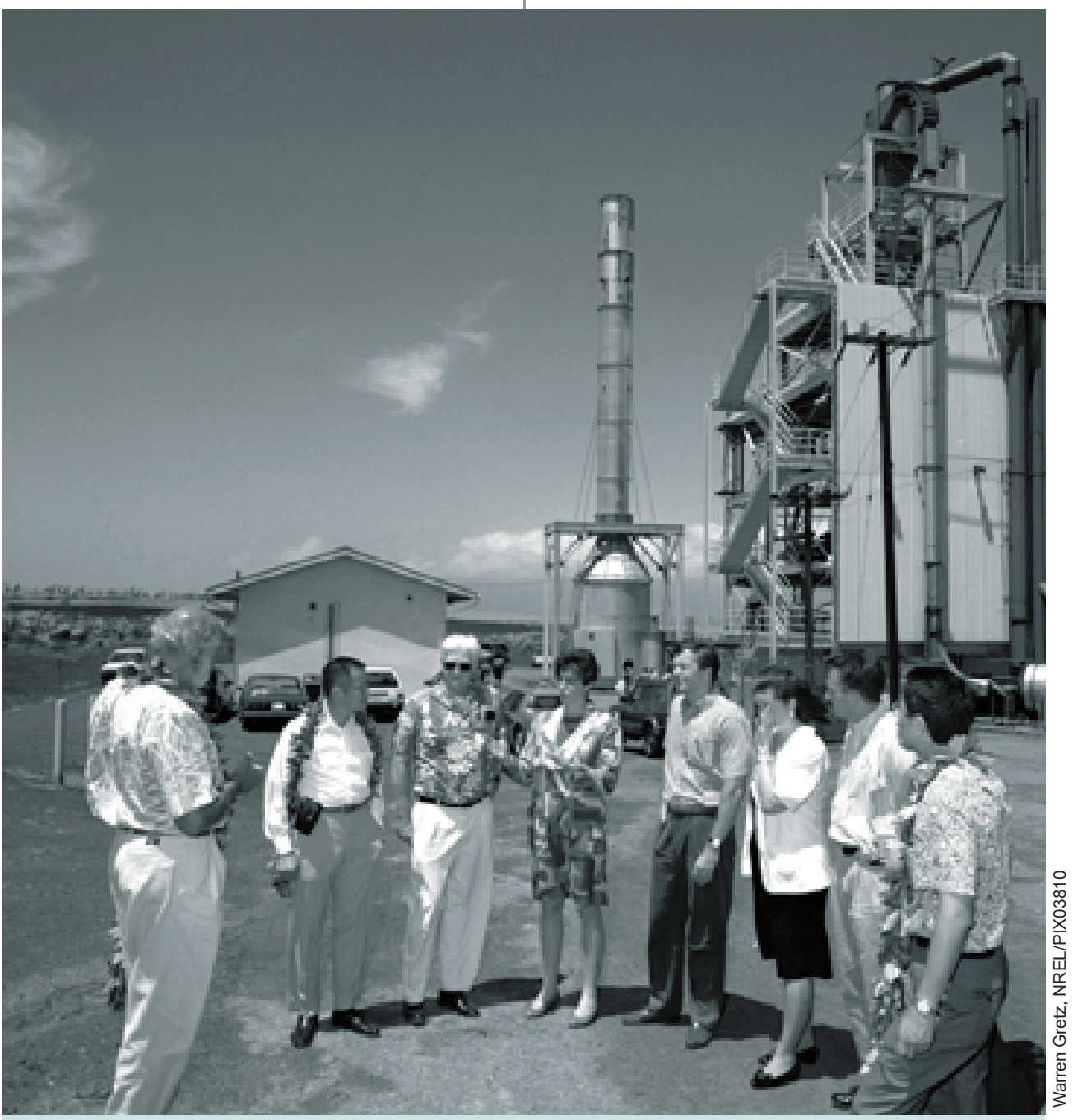

Compared to conventional steam turbines, biomass gasifiers are capable of getting 50\% more electricity from the same energy crop. Hawaii's first gasification facility, at Paia on the island of Maui, is pictured receiving a traditional blessing on dedication day.

The experiment shows how the sugar mills can generate more electricity with the same resources and make more money from selling power to the utility; this benefits the local sugar industry by helping to keep Hawaiian sugar competitive in worldwide markets. 


\section{Wind Power}

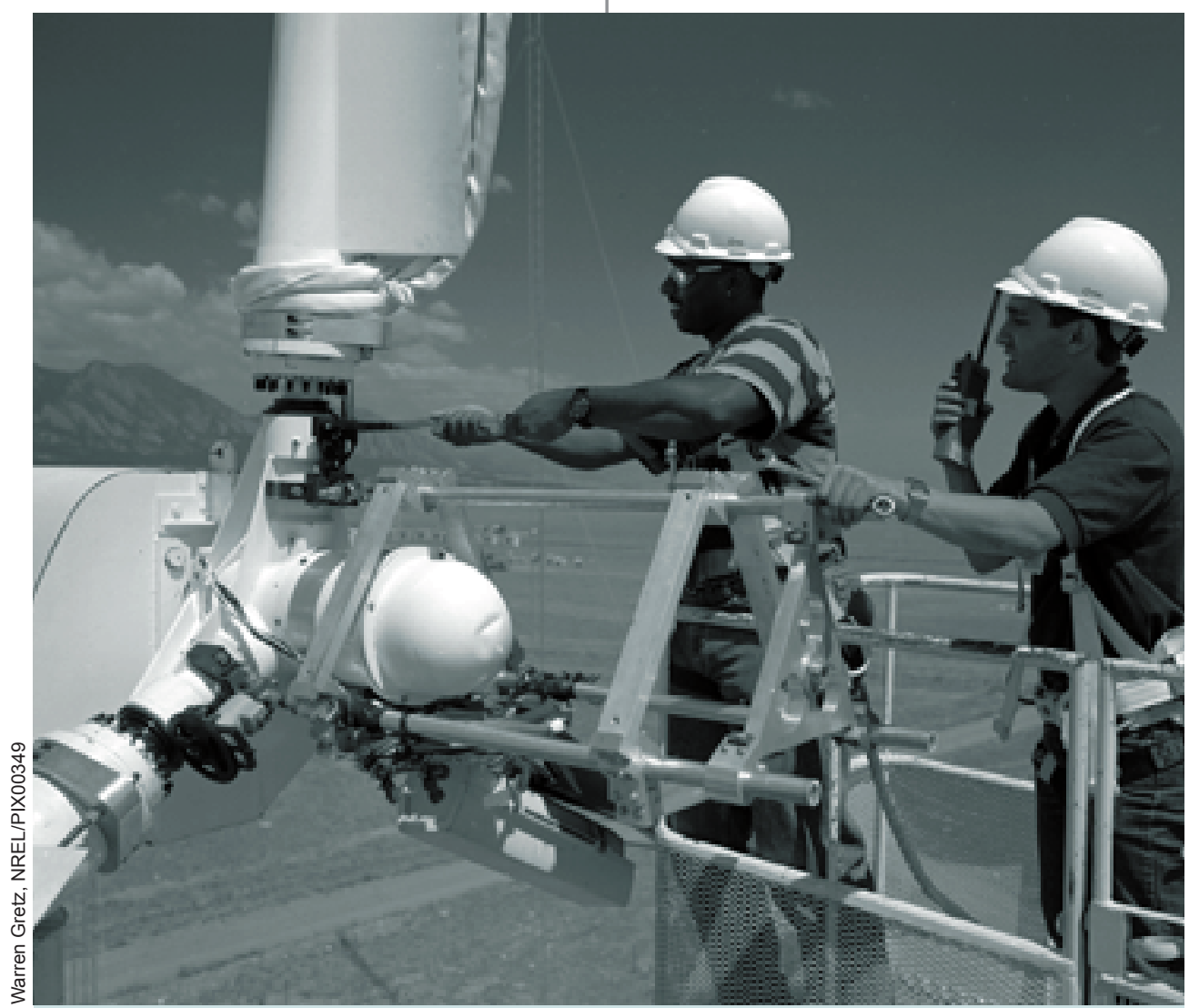

The wind industry pays more than $\$ 31$ million each year in salaries to its employees. Most jobs in the industry are related to operating and maintaining existing wind power plants.

\section{Overview}

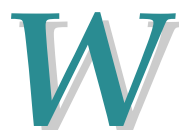

ind energy currently accounts for around $2 \%$ of the country's renewablesource generating capacity. In 1995, total wind generating capacity was approximately $1800 \mathrm{MW}$, most of it (1600 MW) installed in California.

The American Wind Energy Association (AWEA) reports that, in 1992, approximately 1260 people were directly employed in the more than 50 firms that make up California's wind industry. When indirect employment (about 4350 jobs) is added, the industry supported around 5600 full-time jobs in the state that year. Nearly all wind industry jobs are related to operating and maintaining existing wind power plants. According to AWEA, the
California wind industry pays more than $\$ 31$ million each year in salaries to its employees, and also contributes to local economies by paying roughly $\$ 6.7$ million in property taxes.

Like biomass, wind is a form of renewable energy that has special implications for farmers and rural communities - in this case, mainly because large wind farms have to be sited in relatively open countryside.

\section{"Alone among the alternative} energy technologies, wind power offers utilities pollution-free electricity that is nearly costcompetitive with today's conventional sources."

- Electric Power Research Institute, quoted on the CREST internet site

\section{Success Stories}

\section{Renewable Power for the Midwest}

Utility-scale generation of electricity from wind is particularly suited to the rural areas of the upper Midwest because of the region's tremendous wind resources and wide-open spaces.

In 1994, Northern States Power, Minnesota's largest investor-owned utility, committed to developing at least $425 \mathrm{MW}$ of wind energy capacity by the year 2002. But commercial wind development on any scale was new to this region, and there was some uncertainty about what farmers and other residents would think about this.

So, in 1995, The Minnesota Project and the Clean Water Fund conducted a survey of area residents, primarily rural landowners, including a group of farmers from the Buffalo Ridge area of southwest Minnesota where development of a 25-MW wind power plant was already under way. The response was overwhelmingly positive.

\section{"Wind development is almost} unanimously supported by rural residents. They like the environmental benefits of wind energy, and they love the possibilities of injecting income and jobs into rural communities."

\section{- Harvesting the Wind, a 1995 survey by The Minnesota Project and the Clean Water Fund}

Of the 149 residents surveyed, $98 \%$ were in favor of developing wind resources for electricity, and $92 \%$ felt that renewable energy production could be a significant part of rural economic development - the reasons cited included income generation for landowners and communities ( $87 \%$ of respondents) and job creation $(71 \%)$. 
One of the respondents said that wind energy development would help "make rural communities and farms more self-sufficient economically." Another said it would "allow money to stay at home in the local economy." Still another said it would "raise the spirit of the community so people stay."

\section{Extra Income for Landowners}

Although utility-scale wind projects appear to take up a great deal of land, the wind turbines themselves occupy only about $5 \%$ to $15 \%$ of the land area. The remaining land can be used for other purposes, such as farming, ranching, forestry, or for open space. Farmers can graze cattle or plant their crops right up to the base of the turbine towers, making wind power an ideal complement to agriculture.
"Not only do wind farms interfere little with agricultural operations, the leasing of land for wind turbines can be a major benefit for landowners."

\section{- Powering the Midwest, a 1993 report} by the Union of Concerned Scientists

Although one-time payments for wind rights have been made, wind development companies typically offer lease arrangements under which the dollar amount of payments to landowners varies in proportion to the output of the turbines. In 1993, the Union of Concerned Scientists found that a Midwestern landowner hosting a wind farm under a variable-rate plan "could expect payments of around $\$ 40$ per acre per year on top of earnings from farming or grazing," increasing

\section{How It Works}

The wind blows because of differences in atmospheric pressure created by geography and the temperature differences across the Earth's surface; these temperature variations are caused by variations in the amount of sunshine falling on different areas - for this reason, wind is considered an indirect form of solar energy.

Energy is captured from the wind with wind turbines. The turbines have rotors that usually consist of two or three propeller-like blades mounted on a shaft. Wind turbines are mounted on tall towers, usually 100 feet or more above the ground where the wind is faster and less turbulent. When wind makes the blades turn, the shaft spins a generator to produce electricity.

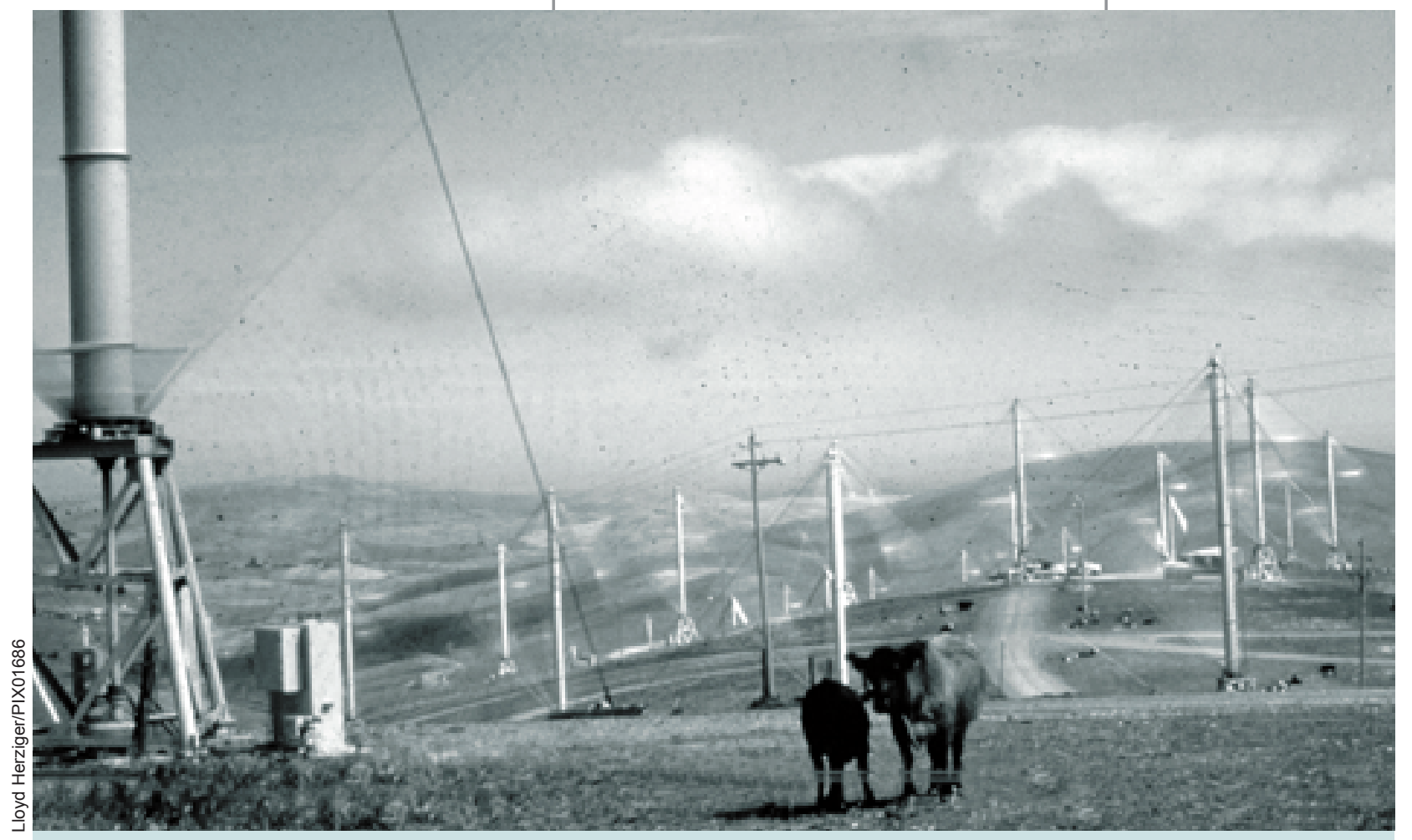

Utility-scale wind plants coexist very well with ranching and farming. Farmers can graze cattle right up to the base of the turbine towers, as on this wind farm operated by Zond Systems at Altamont Pass, California. 


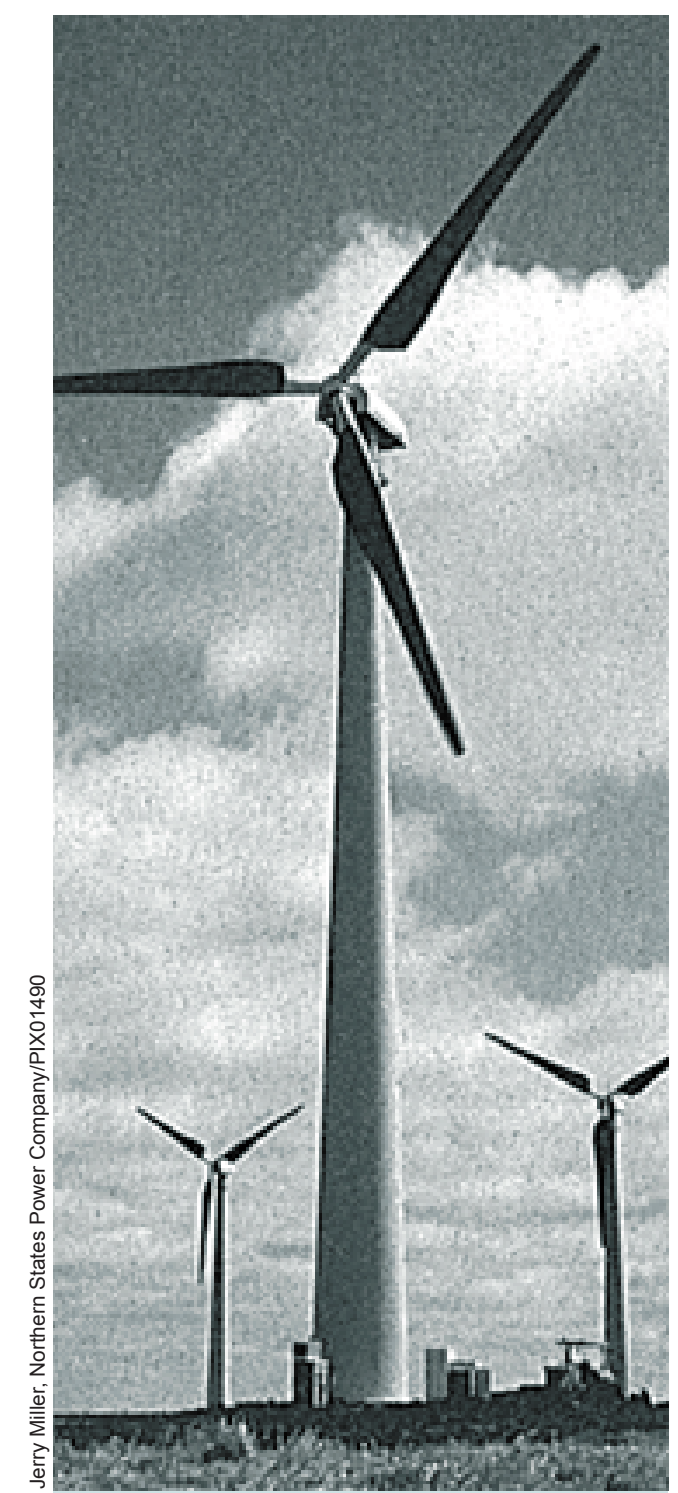

Farmers can earn extra income by leasing land for wind power plants, such as this one on Buffalo Ridge in southwest Minnesota. his return on the land "anywhere from $30 \%$ to over $100 \%$."

The leasing of land for wind power plants pays well in other parts of the country, too. In California, for example, the City of Santa Clara leases 640 acres of land to Zond Systems, Inc., which owns and operates a wind farm at Altamont Pass, one of the largest developed wind sites in the United States. Zond sells the electricity to the local utility, Pacific Gas and Electric Company, and pays a royalty to the city — about \$152,000 in 1994 alone.

The existing lease contains a buyout option for the city, and Santa Clara may purchase the wind power plant from Zond once the city has learned enough to be comfortable managing the project.

According to William Reichmann, a senior electric utility engineer in Santa Clara's Electric Department, "Our lease agreement has been lucrative both financially and in terms of information we gained from the site." In fact, the city has recently signed a lease agreement with Zond for another site that shows promise for wind energy development.

\section{Wind Projects Bring Money to Schools}

The Louisville Gas and Electric Company operates a 35-MW wind farm in Culberson County, Texas, about 100 miles east of El Paso. The Lower Colorado River Authority buys the electricity generated at the wind site and distributes it to its customers. As a result of an innovative partnership with the Texas General Land Office, lease revenues from the wind project go directly into the Permanent School Fund, which helps to finance public schools and universities in Texas; in effect, school children are benefiting financially from the wind energy harnessed in west Texas.
Revenues are expected to total approximately $\$ 3$ million over the 25-year life of the project, or about $\$ 120,000$ annually.

\section{"Public education in Texas will} benefit by receiving millions of dollars in lease money from this project. ... I hope to see more wind power projects on state lands dedicated to the public schools."

- Texas Land Commissioner Garry Mauro, speaking at the dedication of the Culberson County wind project, November 1995

At the other end of the scale, a small school district in northwest Iowa is making money from the sale of electricity generated by its very own wind turbine. A project that started out as a response to environmental concerns turned out to have a substantial financial benefit for the local community.

The project began in 1990, when a group of high school biology students challenged Harold Overmann, superintendent of the Spirit Lake Community School District, to find a renewable source of energy for the district. Instead of ignoring them, Overmann took them up on their challenge. District staff began a dialog with the local utility company, Iowa Electric, and investigated various renewable energy technologies before deciding on wind power. They then gathered data on wind speeds at the proposed site and worked hard to find a way to finance the project.

Three years later, at a cost of $\$ 238,000$, the district installed a wind turbine at the local elementary school. A grant from DOE paid for half of the cost and a loan from the Iowa Department of Natural Resources covered the rest. Since then, the turbine has been generating $324,000 \mathrm{kWh}$ of electricity annually, worth about 
$\$ 25,000$. The elementary school, however, uses only $\$ 20,000$ worth of electricity. Surplus power is sold to Iowa Electric. With the $\$ 25,000$ yearly savings, the loan will be completely paid back within a five-year period.

\section{"I've never done anything that's} been so popular in the community."

- Superintendent Harold Overmann, Spirit Lake School District, quoted on the lowa Department of Natural Resources internet site

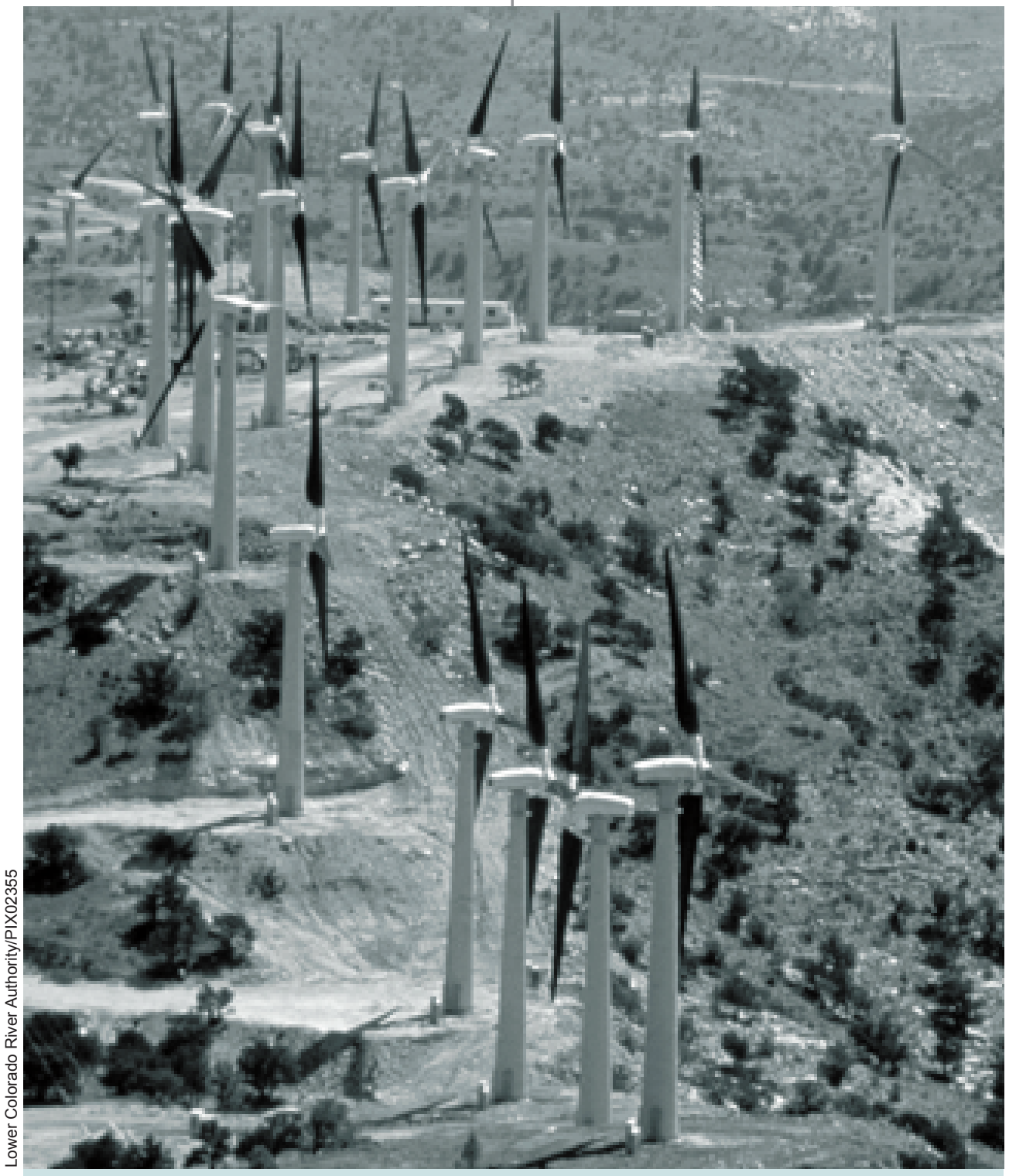

Lease revenues from this west Texas wind farm are used to finance public education in Texas. The local electric utility leases the land from the state, paying an average of $\$ 120,000$ annually.
Once the district's loan is repaid, all of the electricity generated by the turbine will represent a direct saving to the district and, therefore, local taxpayers. The money saved can be directed into education. "We're using our noninstructional costs for instructional costs," said Overmann. "With the money we save we can fully equip a computer lab every year instead of paying for electricity."
Not only is the district helping itself, it is also saving the environment, just as it set out to do. The electricity generated by the wind turbine replaces 225 tons of coal and prevents 750,000 pounds of carbon dioxide emissions from polluting the air every year. "We're proud that we are helping to solve the pollution problem," said Overmann. 


\section{Photovoltaics: Eectricity from Sunlight}

\section{Overview}

$P$ hotovoltaics is a technology in transition. Photovoltaic (PV) power has long been costcompetitive in a variety of off-grid applications; and as the cost of PV electricity continues to fall, this environmentally benign technology is becoming increasingly attractive to electric utility companies. In the United States, photovoltaics is currently making the move from primarily remote, stand-alone applications to utility grid support.

Acording to the Solar Energy Industries Association (SEIA), total grid-connected photovoltaic generating capacity in 1994 was about 18 MW, spread across 36 states. Although stand-alone applications are difficult to quantify because they are so widely dispersed, there are an estimated 25,000 homes in the United States powered exclusively by photovoltaics.

More than 850 U.S. companies are currently involved in the manufacture and sale of photovoltaic modules and system components. The industry brings in more than $\$ 300$ million in revenues annually and employs 15,000 people - most of them in high-quality jobs, such as manufacturing, engineering, sales, installation, servicing, and maintenance.

International sales continue to drive the PV industry. The largest market for photovoltaics is in the developing world, where two billion people still do not have electricity in their homes. Photovoltaic systems are particularly well suited to this market because of their high reliability, their suitability for applications of almost any size, and the fact that they do not need costly transmission lines. Approximately 70\% of U.S. photovoltaic manufacturing output is exported.

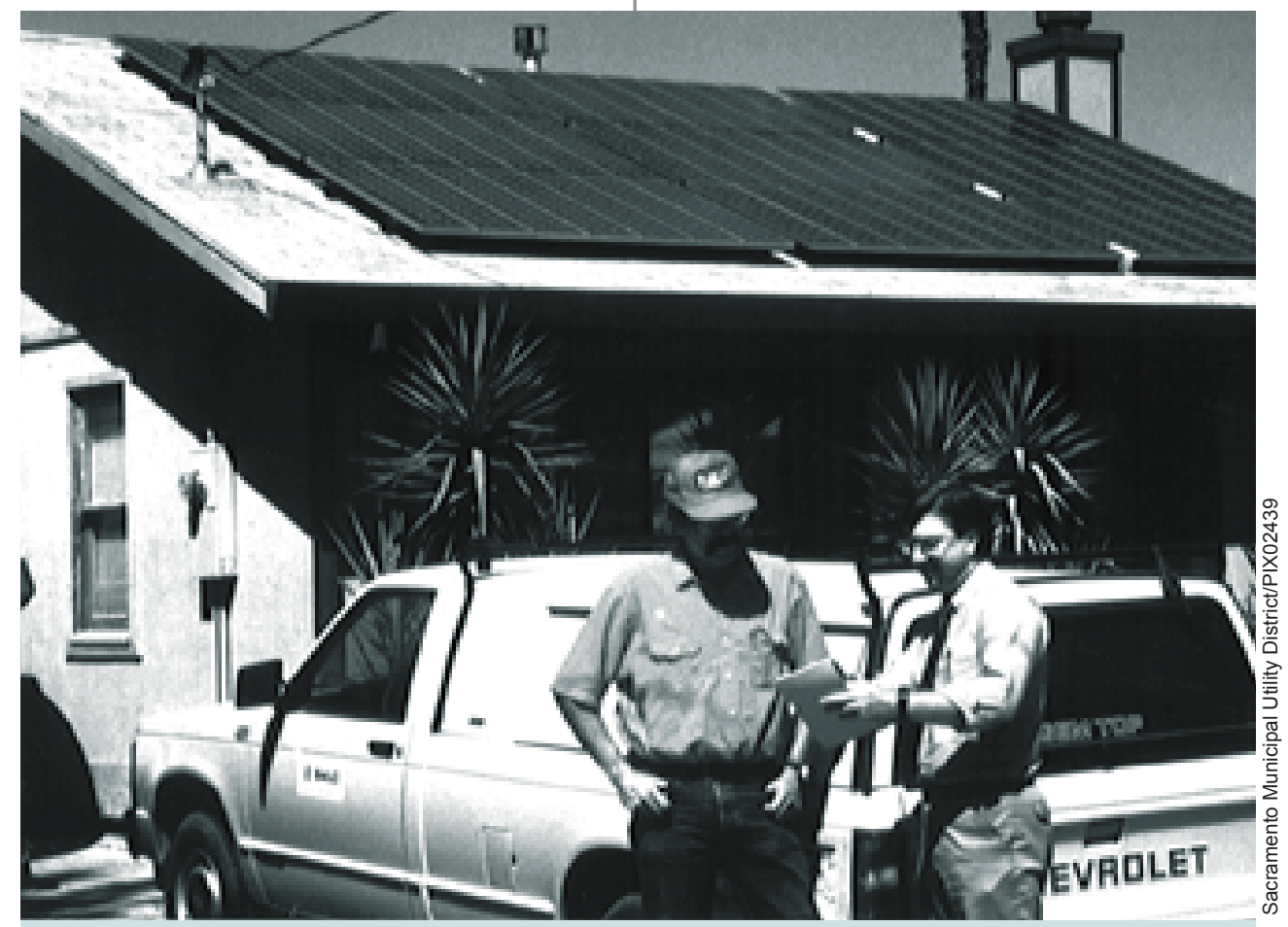

Through its PV Pioneers program, the Sacramento Municipal Utility District (SMUD) installs and operates grid-connected, rooftop PV systems on customers' homes. The program creates jobs in the utility's service area and reduces the need for SMUD to purchase electricity from other regions.

\section{Success Stories}

The United States leads the world in photovoltaic research and manufacturing, accounting for $43 \%$ of global PV module production in 1995 . The growing international popularity of photovoltaics is creating an increasingly buoyant domestic PV industry, and U.S. manufacturers are scaling up their production facilities to take advantage of emerging markets. These expansions are creating skilled jobs in several states.

\section{U.S. Manufacturers Lead the Way}

Siemens Solar Industries (SSI), based in Camarillo, California, is the world's largest manufacturer of photovoltaic cells and modules. In 1995, the company shipped $17 \mathrm{MW}$ of photovoltaic modules, representing half of U.S. production and $21 \%$ of total world production that year. To help meet growing worldwide demand, SSI completed a $\$ 3$ million expansion of its facility in Vancouver, Washington, in February 1996. The expansion created 33 new jobs in the Vancouver area, and all work on the facility was awarded to local contractors, further contributing to the local economy. SSI employs a total of approximately 350 people at its facilities in California and Washington.

Solarex, the second largest PV manufacturer in the United States, has been in business for over 20 years. During the late 1970s and early 1980s, as oil prices rose, major oil companies began investing in renewable energy as a hedge against an uncertain future in fossil fuels. Amoco Corporation bought Solarex in 1983. Most of the oil 
companies concentrated on developing their renewable energy for the longterm utility market; in other words, they were not very concerned with short-term profitability. Amoco, on the other hand, treated Solarex as part of the business from the very beginning, producing revenues from existing products at the same time as investing in technology development.

Today this strategy is paying off. In 1995, Solarex captured 27\% of the U.S. market (12\% of the global market), with total sales of $\$ 45$ million. In January 1996, the company broke ground on a new wing at its manufacturing facility in Frederick, Maryland, which already employs 240 people.
"This dynamic expansion project by Solarex will provide the kind of high quality [jobs] that Maryland needs to continue building a prosperous, vibrant economy."

- James Brady, Secretary of the Maryland Department of Business and Economic Development (Solar Industry Journal, First Quarter, 1996)

Solarex is also building a $\$ 25$ million manufacturing plant in James City, Virginia. The company was lured there by state incentives specifically designed to create jobs and strengthen the state's economy by attracting PV manufacturing companies to the area. The new plant will employ a total of approximately 80 people.

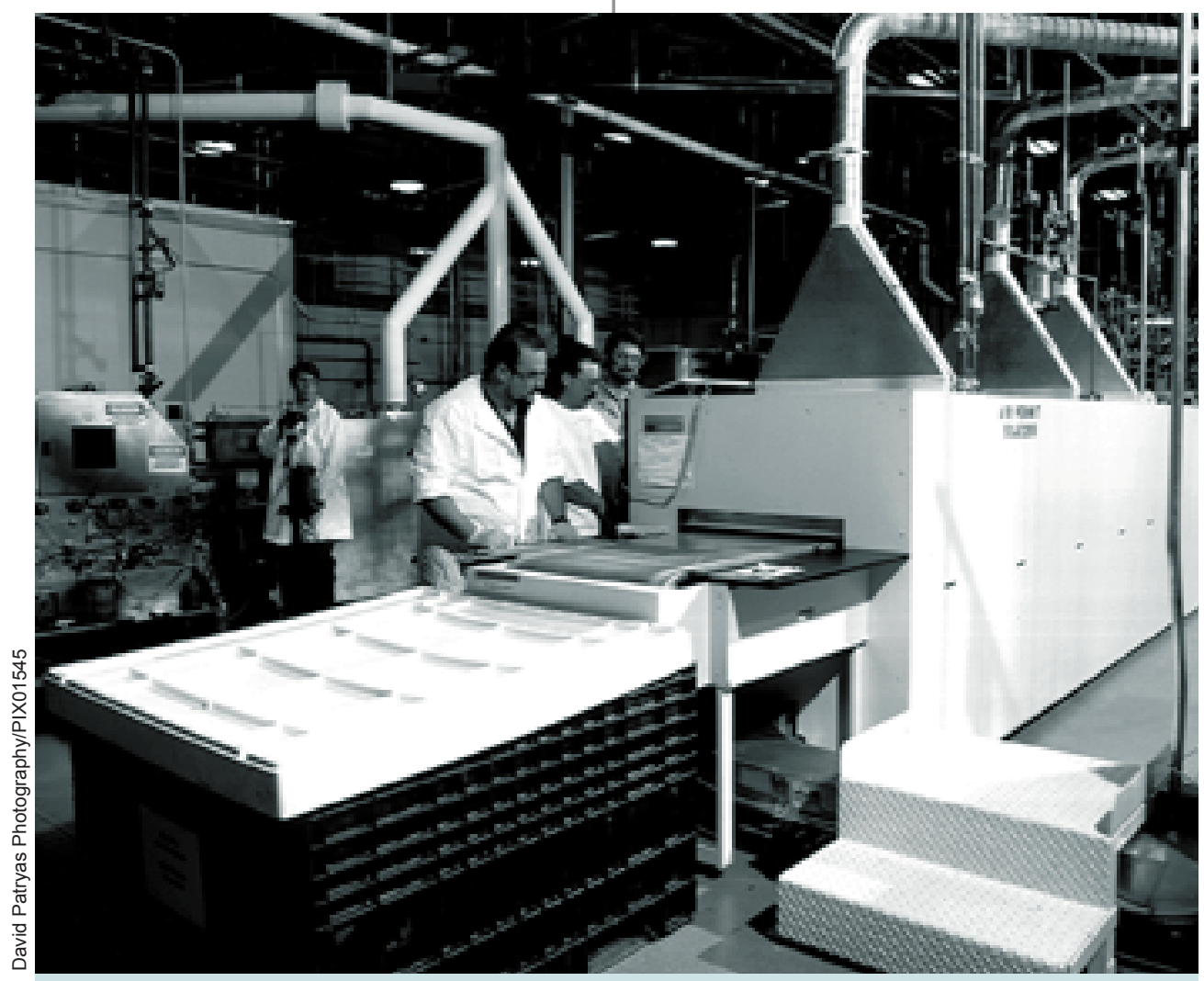

U.S. manufacturers are expanding their output to meet the growing demand for $P V$ systems. This creates skilled jobs at production facilities in several states, such as this thin-film plant in Golden, Colorado. 


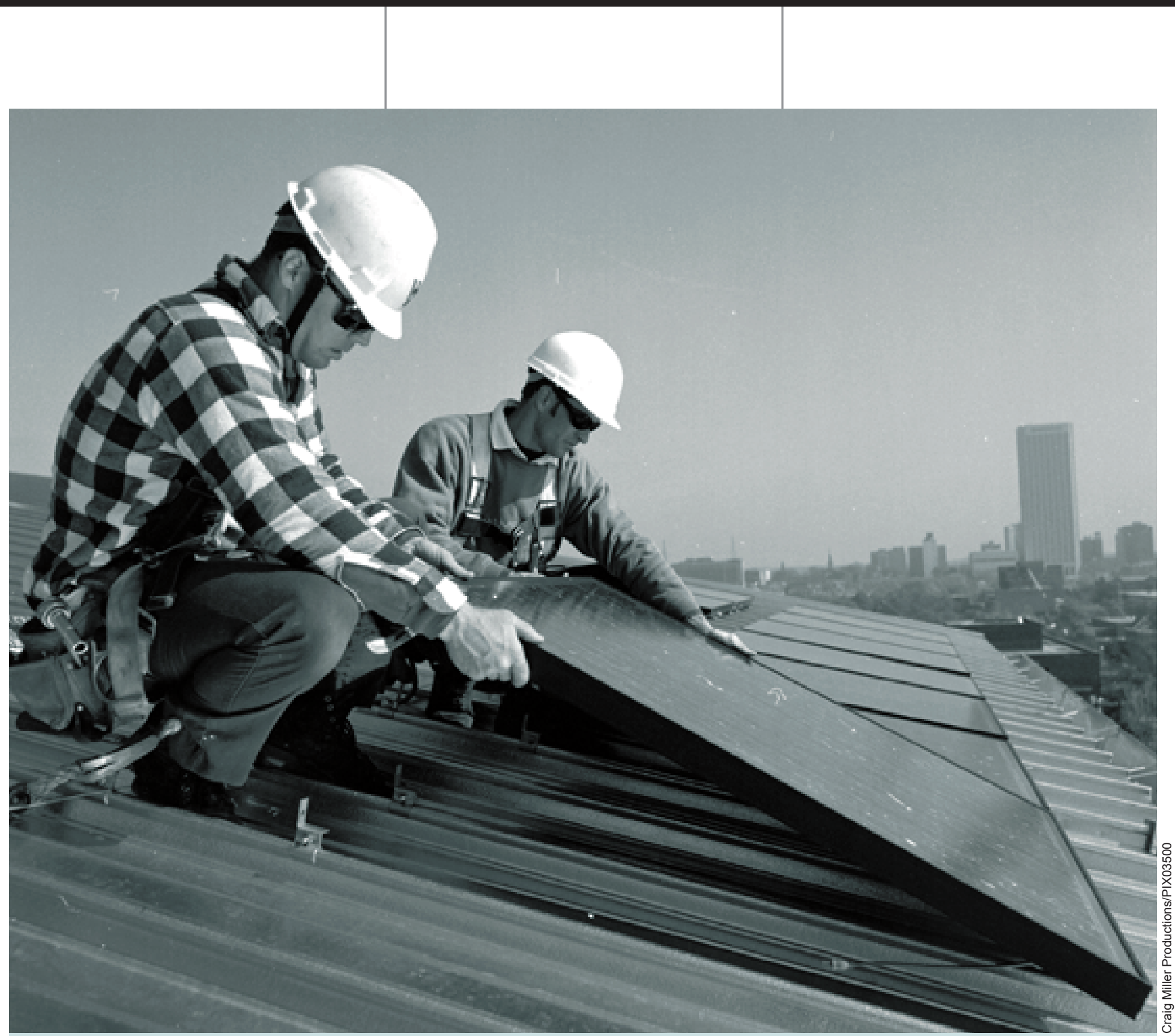

The U.S. PV industry employs 15,000 people, most of them in high-quality jobs, including installation, servicing, and maintenance. This 340-kW system was installed on the roof of the aquatic center for the 1996 Summer Games in Atlanta, Georgia. It is the world's largest building-integrated, rooftop PV system.

Another PV manufacturer, Atlantis Solar Systems / Solar Building Systems, also took advantage of Virginia's incentives; Atlantis is constructing a production facility in Cape Charles that will create 25 jobs.

According to an August 1995 article in The Newport News Daily Press, "Virginia, whose economy once was rooted in tobacco, is leaving its plantation past behind and heralding its future in high technology." Virginia has increased its investments in science and math education at all levels, and is looking to attract industries that will provide high-paying jobs for its home-grown graduates in the fields of engineering, chemistry and science. "PV is exactly the kind of industry that Virginia wants to encourage," said Ann Broadwater of the Virginia Department of Development.

Other U.S. manufacturing companies have also been expanding their operations. Solec International, for example, the country's third largest PV manufacturer, more than doubled its workforce between 1993 and 1996. The company now employs 130 people. 
And AstroPower, Inc., a tiny start-up venture 10 years ago, now has 145 employees and annual revenues exceeding $\$ 10$ million, $80 \%$ of which are from exports.

\section{Growing Utility Interest}

According to the Utility PhotoVoltaic Group (UPVG), “UPVG's market evaluation work has shown that PV can make a contribution to every utility in every part of the country." UPVG is a group of more than 80 electric utilities formed in 1992 to investigate utility applications of photovoltaics. Today, 39 U.S. utilities are actively testing grid-connected photovoltaic systems, including California's Sacramento Municipal Utility District (SMUD), a UPVG member and, with 480,000 customers, the nation's fifth largest customer-owned utility.

More than half of SMUD's projected load requirements have been met with renewable-source electricity, such as the utility's PV Pioneers program, and energy efficiency programs. SMUD also operates the country's largest PV power plant, a 2-MW facility on the grounds of the utility's now-closed Rancho Seco nuclear power plant. These programs have created jobs within the utility's service area and mean that SMUD has to purchase less power from other regions.

\section{"Our customers want more from} us than just a good price; they want long-term reliability, a clean environment and local economic development. Solar can help us meet these needs."

- Don Osborn, SMUD solar program manager (Solar Industry Journal, Third Quarter, 1995)
A growing number of electric utilities are also becoming familiar with the advantages of photovoltaic power for remote applications. In 1994, Southern California Edison (SCE) started an off-grid PV program called Partnership with the Sun. John Bryson, SCE's chairman, says it is a win-win program: "Homeowners and businesses in remote locations get clean, quiet electricity. Independent contractors get jobs and construction projects. And Edison is able to serve new customers who otherwise have no dependable source of power."

\section{Saving Money for Ranchers}

Photovoltaics can be a winner for rural electric cooperatives. KC Electric Association, a rural electric cooperative in eastern Colorado, is saving its members money by providing them with photovoltaic power. The association serves 4000 square miles of prairie with an average of only two customers per mile of distribution line. Every year, winter storms knock out as many as 1000 utility poles and 38 miles of lines. With replacement costs of $\$ 10,000$ per mile of line, the association has been spending up to $\$ 380,000$ on maintenance every year.

The lines provide little revenue. About half of the association's customers use the electricity primarily to power small irrigation pumps. In 1990, KC Electric began using photovoltaics as a more practical and affordable alternative to replacing damaged distribution lines serving remote livestock wells or extending lines to new well sites. The cooperative can provide PV-powered water pumping at a cost of $\$ 1800$ to $\$ 6000$ per well saving its members thousands of dollars when compared with the cost of providing grid electricity.

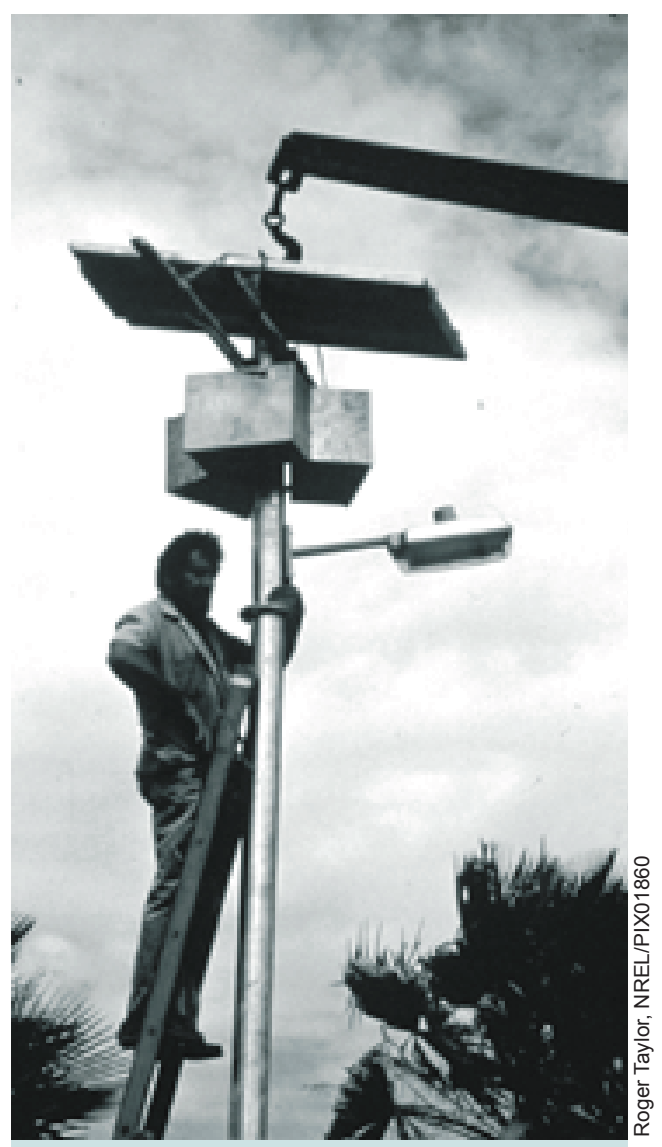

Worker installing a gridindependent, PV-powered street light. 


\section{Solar Thermal Eectricity: Power from the Sun's Heat}

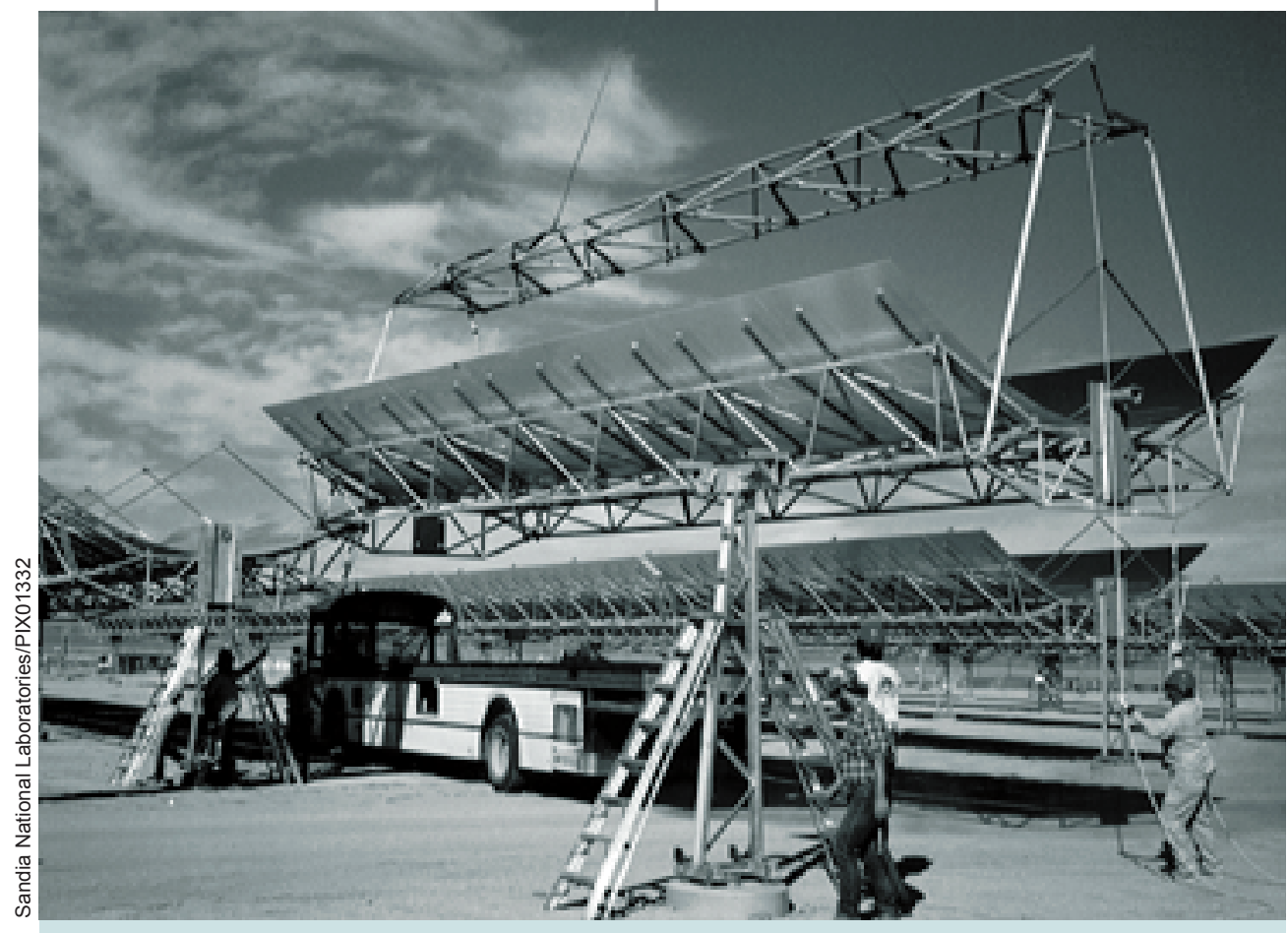

The assembly system used by Luz International for its parabolic-trough generating plants.

\section{Overview}

0 olar thermal electric systems provide utilities with a variety of modular power options, some of which can be constructed in a relatively short period of time. There is currently about $365 \mathrm{MW}$ of utilityconnected solar thermal generating capacity, all of it installed in California.

More than 250 people are directly employed in the operation and maintenance of $354 \mathrm{MW}$ of solar thermal trough systems in California. A fossilfuel-fired plant producing the same amount of electricity would employ only about 100 people. A 1994 study by the California Energy Commission also revealed that solar thermal power plants yield twice as much tax revenue as conventional, gas-fired plants producing the same amount of electricity.

\section{Success Stories}

The three types of solar thermal electric technologies - troughs, power towers and dish systems - are in different stages of development. Troughs have a proven track record, power towers are in the demonstration stage - which means that they are close to commercialization - and dish/engine systems are still under development.

\section{Solar Troughs: Proven Success}

Parabolic trough systems have already proven themselves in the field. Nine solar electric generating systems (SEGS) totaling $354 \mathrm{MW}$ have been operating successfully in California, some for more than a decade. Their availability to produce power when the sun is shining is greater than $92 \%$, a statistic that rivals utility-scale power plants of any type.

The SEGS systems were all built by a private company, Luz International, between 1984 and 1991. These systems are still operating successfully, producing more than $90 \%$ of the world's solar thermal electricity and saving the energy equivalent of 2.3 million barrels of oil every year.

\section{"The SEGS provide employment} to over 250 skilled operators, craftspersons, and professionals, and millions of dollars in contracts to local vendors."

- KJC Operating Company, which manages five of the SEGS plants (Clean Power Day 1996 prospectus)

In 1991, Luz employed more than 700 people. According to Michael Lotker, formerly Luz's vice president of business development, each of its 80-MW SEGS plants required about 1 million job hours (500 job years) to construct. Because maintenance of the SEGS solar field is more labor-intensive than maintenance of a fossil-fuel power plant, the solar plant pays higher payroll taxes.

It has been estimated that, over their 30-year life, the operation and maintenance of each of the 80-MW plants will contribute $\$ 11.6$ million in taxes to the local government, $\$ 65.8$ million to the state, and \$228.9 million to the federal government.

\section{The Solar Two Power Tower}

Solar Two, in California's Mojave Desert, is a $10-\mathrm{MW}$, second-generation demonstration project to confirm the technical and economic viability of power towers. The plant uses a field of 1926 heliostats located around a 300-foot tower to focus solar radiation onto a central receiver. Molten salt is used as the heat exchange and storage medium, providing up to three hours of dispatchable power after the sun goes down.

The project has been financed by a consortium of electric utilities and high-tech companies (led by Southern 
California Edison) and the U.S.

Department of Energy. The industry consortium is currently involved in discussions about using the experience gained from Solar Two to build a commercial 30-100 MW power tower in Nevada, a project that would create many new jobs.

\section{"Solar Two represents both a new} source of clean power for California and neighboring states, and a new source of export technology for America and jobs for American workers."

- John Bryson, chairman of Southern California Edison, at the Solar Two dedication in June 1996

Solar Two gives an indication of the range of jobs that would be required to operate and maintain power towers once they are commercialized. The demonstration project employs nine full-time staff: three people to operate the plant's control systems plus a maintenance crew consisting of two full-time mirror washers and their truck driver, an instrument technician, an electrician, and a mechanic.

\section{Dish/Engine Systems: Future Opportunity}

Although dish/engine systems are still under development, the prospects for this technology look promising. The systems are transportable and are appropriate for both on-grid and remote applications. Science Applications International Corporation (SAIC), a solar dish developer, plans to produce five precommercial, $25-\mathrm{kW}$ systems by 1999 . SAIC also expects to be producing 1000 commercial dish / engine systems per year by 2002, creating 500 high-tech jobs at a manufacturing facility in the Southwest and an additional 1000 jobs at supplier facilities throughout the United States.

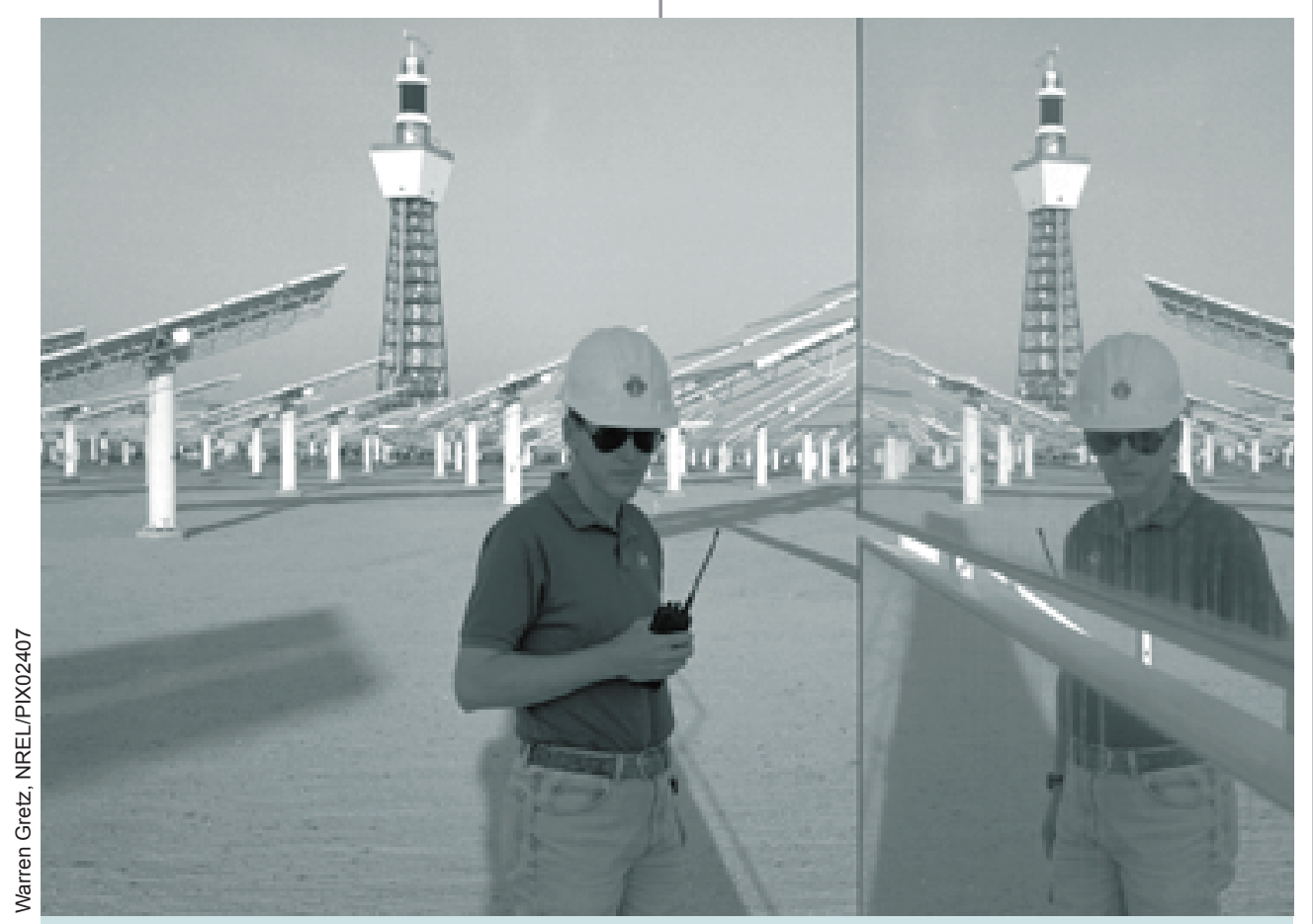

Solar Two technician Hugh Reilly inspecting one of the 1926 heliostats (mirrors) that track the sun during the day. Power towers provide a variety of jobs in systems operation and maintenance.

\section{How It Works}

Unlike photovoltaic systems, which generate electricity directly from light, solar thermal power systems use the heat from the sun's rays to generate power. Reflective surfaces concentrate the sun's rays to heat a receiver filled with oil or another heat-exchange fluid. The heated fluid is then used in some form of heat engine to generate electricity. Mechanical drives slowly turn the reflective surfaces during the day to keep the solar radiation focused on the receiver. There are three main types of solar concentrators used in solar thermal electric systems:

\section{Parabolic trough systems concentrate} solar rays onto a receiver pipe located along the focal line of a curved, troughshaped reflector. The synthetic oil flowing through the pipe is heated to as much as $750^{\circ} \mathrm{F}$. The hot oil is used to boil water to make steam, which runs a conventional steam turbine to generate electricity.

Power towers, also called central receivers, use a field of sun-tracking mirrors (heliostats) to reflect solar radiation onto a receiver that sits on top of a tall tower. The fluid in the receiver is heated to as much as $1050^{\circ} \mathrm{Fbefore}$ being passed through a heat exchanger to produce the steam used to generate electricity.

Parabolic dish systems are similar to trough systems except that they use a dish-shaped reflector. The dish concentrates solar radiation onto a receiver mounted at the focal point of the dish, heating the receiver fluid to as much as $1500^{\circ} \mathrm{F}$. Instead of boiling water to run a steam turbine, most dish systems today generate electricity by using the hot fluid to run a Stirling engine mounted at the dish's focal point. 


\section{Ceothermal Energy: Power from the Earth}

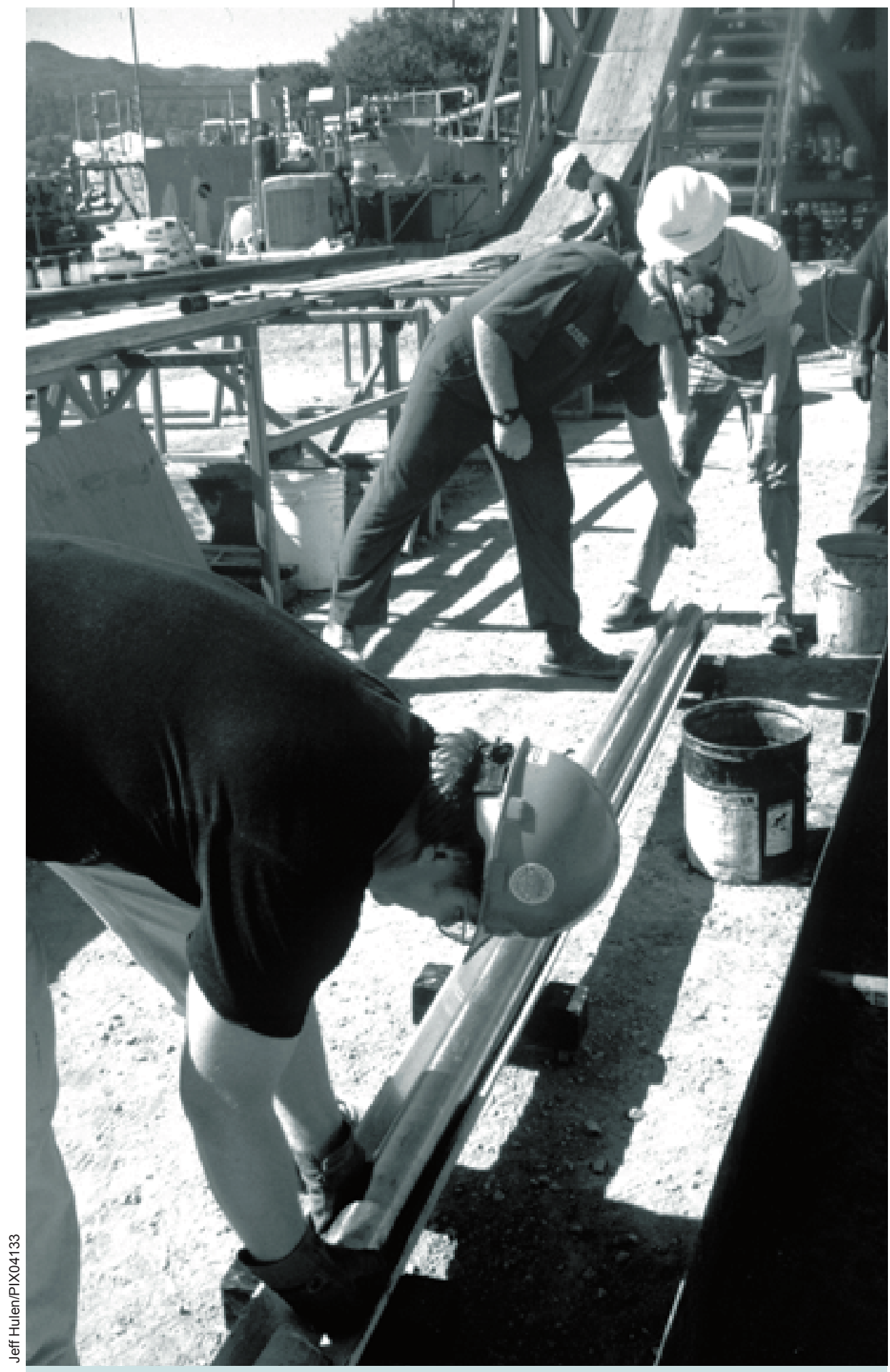

The drilling of production wells, such as these at The Geysers (above) and Imperial Valley (opposite) in California, accounts for a third to a half of the cost of a geothermal project. About 10,000 people are directly employed in the geothermal electric industry.

\section{Overview}

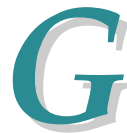
eothermal power is a commercially proven renewable resource. Geothermal generating capacity in the United States is currently about $2300 \mathrm{MW}$, distributed among baseload power plants located in four states - California, Nevada, Utah, and Hawaii. Geothermal energy accounts for around $2 \%$ of the country's renewable-source electric generating capacity.

In 1996, the U.S. geothermal energy industry as a whole provided about 12,300 direct domestic jobs, and an additional 27,700 indirect domestic jobs. The electric generation part of the industry employed about 10,000 people to install and operate geothermal power plants in the United States and abroad, including power plant construction and related activities such as exploration and drilling; indirect employment was about 20,000.

\section{Success Stories}

\section{Providing Jobs and Tax Revenue}

Nevada's geothermal plants produce about $210 \mathrm{MW}$ of electricity, saving energy imports equivalent to 800,000 tons of coal or three million barrels of oil each year. Although California has much greater installed capacity, Nevada, with just over a million residents, uses more geothermal energy per capita than anywhere else in the country.

Taxes received from geothermal operations are a significant source of revenue for Nevada's local and state governments. In 1993, Nevada's geothermal power plants paid $\$ 800,000$ in county taxes and $\$ 1.7$ million in property taxes. In addition, the U.S. Bureau of Land Management collects nearly $\$ 20$ million each year in rent and royalties from geothermal plants 


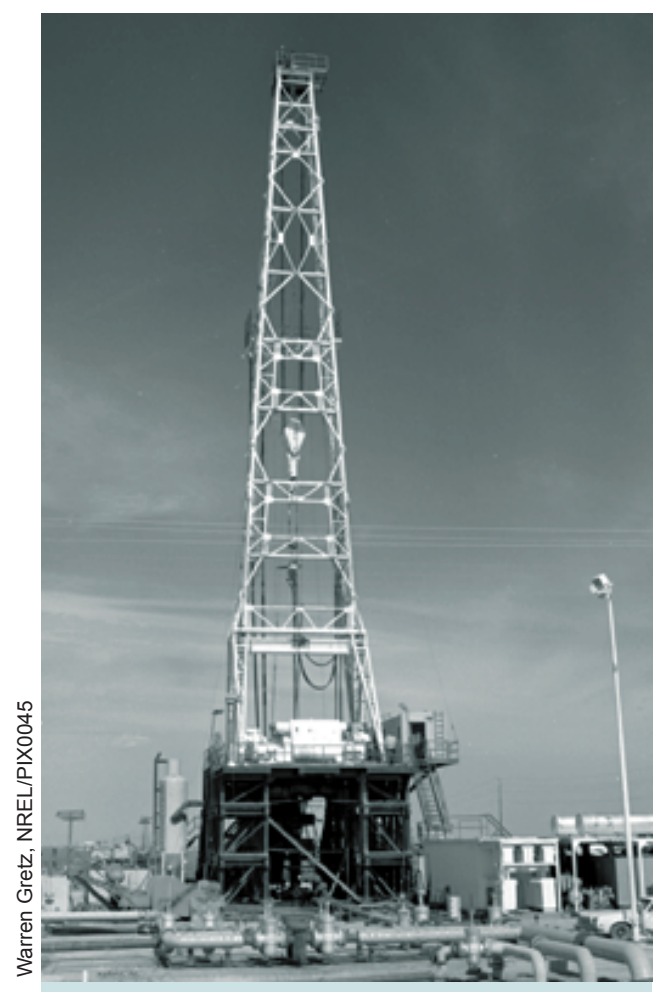

Geothermal production well at Imperial Valley, California.

producing power on federal lands in Nevada - half of these revenues are returned to the state.

"Net proceeds tax, property tax and county tax payables have increased for geothermal plants throughout the state, especially in rural areas."

- Thomas Flynn, University of Nevada (Geo-Heat Center Bulletin, May 1996)

The California Energy Company (CalEnergy) operates geothermal power plants in California, Nevada and Utah. In California, the company employs 226 people at its Salton Sea geothermal field in the Imperial Valley and 121 people at the Coso geothermal field. In 1995, CalEnergy contributed more than $\$ 45$ million to California's tax base through income taxes, payroll taxes, local (county) taxes and unemployment taxes.
Most of the electricity produced from the Coso geothermal field comes from power plants located on U.S. Navy land near China Lake in Inyo County. Tax revenues paid to Inyo County by CalEnergy amount to more than $20 \%$ of the county's annual income. In addition, the Navy gets royalties and cheaper electricity from the plants; in one year alone (1993), the Navy saved $\$ 4.2$ million in electricity costs, which equates to a one-third reduction in the total electricity bill for the China Lake Naval Air Weapons Station.

\section{Displacing Imported Fuel Oil in Hawaii}

Hawaii has no conventional energy resources and is forced to import virtually all of its energy, including every drop of oil. Fully $85 \%$ of the state's electricity is generated from petroleum products, primarily fuel oil, compared with only $3 \%$ for the United States as a whole. Importing oil represents a significant drain on the state's economy, and creates a strong incentive to develop domestically available renewable energy resources.

Geothermal energy has been identified as perhaps the best near-term indigenous resource to meet the energy needs of the "big island" of Hawaii. A single 25-MW geothermal plant on the island produces $19 \%$ of the baseload needs of the Hawaiian Electric Light Company, replacing 1000 barrels of imported fuel oil per day.

\section{"The [Salton Sea Geothermal] Project will provide economic benefits to the State of California in the form of additional jobs and an expanded tax base."}

- David Sokol, CalEnergy chairman (CalEnergy press release, April 1995)

\section{How It Works}

Geothermal ("Earth-heat") energy comes from the residual heat from the Earth's formation and from the radioactive decay of atoms deep inside the Earth. This heat is brought up to the Earth's crust by molten rock (magma) and by conduction through solid rock. There it raises the temperature of groundwater trapped in the fissures and pores of underground rock, forming zones called hydrothermal reservoirs. Geothermal power plants are driven by hot water and steam produced from wells drilled into these hydrothermal resources.

In most geothermal power plants, the steam from hydrothermal reservoirs is used to generate electricity by spinning a turbine generator directly; in others, the geothermal hot water is used to vaporize a working fluid that boils at a low temperature. This vapor is then piped to a turbine to generate electricity.

Potential geothermal energy reserves are so large that they are considered inexhaustible. Nevertheless, the fluid in individual hydrothermal reservoirs can be depleted to the point where the reservoir becomes economically unproductive. For this reason, sustainable use of specific hydrothermal resources always requires the reinjection of water into the underground reservoir to maintain pressure. Injection of fluids from the Earth's surface can also help to increase output from reservoirs after they have become depleted, a strategy that is being pursued at The Geysers field in California. 


\section{For More Information}

\section{General Contacts}

Center for Renewable Energy and Sustainable Technology (CREST) 1200 18th Street NW, \#900

Washington, DC 20036

Tel: (202) 530-2202

Web: http:/ / www.crest.org

CREST's Web site has information on documents, databases, discussion groups, and organizations in the sustainable energy field.

\section{Energy Efficiency and Renewable} Energy Clearinghouse (EREC) PO Box 3048

Merrifield, VA 22116

Tel: (800) DOE-EREC (363-3732)

Fax: (703) 893-0400

E-Mail: doe.erec@nciinc.com

This free service has information on renewable energy and saving energy. It is funded by the U.S. Department of Energy.

\section{Energy Efficiency and Renewable} Energy Network (EREN)

Web: http:/ / www.eren.doe.gov

The on-line version of EREC. An excellent resource, with links to hundreds of related sites.

\section{National Association of Regulatory} Utility Commissioners

Subcommittee on Renewable Energy PO Box 684

Washington, DC 20044

Tel: (202) 898-2200

Web: http:/ / www.erols.com/naruc

\section{Biomass}

National BioEnergy Industries Association

122 C Street NW, Fourth Floor

Washington, DC 20001-2109

Tel: (202) 383-2540

Web: http:/ / solstice.crest.org/ renewables/nbia

Publishes the quarterly magazine, Biologue, which includes information about regional biomass energy programs.

\section{Wind}

American Wind Energy Association 122 C Street NW, Fourth Floor Washington, DC 20002-2109

Tel: (202) 383-2500

Web: http:/ / www.igc.apc.org/awea

AWEA can provide information on the use of wind energy for utility applications across the country.

\section{Solar (Photovoltaics and Solar Thermal Electric)}

Solar Energy Industries Association 122 C Street NW, Fourth floor Washington, DC 20002 Tel: (202) 383-2600

Web: http:/ / solstice.crest.org/ renewables/seia

\section{Geothermal}

\section{Geothermal Resources Council}

2001 Second Street, Suite 5

PO Box 1350

Davis, CA 95617-1350

Tel: 916/758-2360

Web: http:/ / www.geothermal.org 
Text in italics refers to other glossary entries.

Biomass - All of the Earth's plant and animal matter. In the renewable energy industry, biomass usually refers to the wood, wood-processing residues, agricultural residues, and energy crops that are used to create electricity, generate heat, or produce liquid transportation fuels.

Energy crops - Crops grown specifically for their fuel value, including food crops such as corn and sugarcane, and nonfood crops such as willow trees and switchgrass.

Fossil fuels - Energy sources formed by the decay of plants, dinosaurs, and other animals over millions of years; coal, oil, and natural gas are fossil fuels. These energy reserves form so slowly in comparison to our rate of energy use that they are regarded as a finite resource.

Geothermal energy - Heat energy stored in the Earth's crust, which can be harnessed to produce electricity or to heat water and living spaces.

Gigawatt (GW) - 1,000,000,000 watts (see Watt)

Hydropower - The energy of flowing water, which can be harnessed to make electricity or to do mechanical work.

Kilowatt (kW) - 1000 watts (see Watt)
Kilowatt-hour (kWh) - A unit of electrical energy, equal to 1000 watts of power delivered for a period of one hour (see Watt)

Megawatt (MW) - 1,000,000 watts (see Watt)

Multiplier effect - Additional jobs and income created in the economy as a result of an initial expenditure. See page 2 for a detailed explanation.

Municipal solid waste - Trash or garbage; it can be used to produce heat or electricity by burning it or by capturing the gases it gives off and using them as fuel.

Nonrenewable fuels - Fuels that are not naturally replaced as we use them. This includes fossil fuels, nuclear fuels, and municipal solid waste.

Photovoltaics - A technology for using semiconductors to directly convert light into electricity.

Renewable energy - Sources of energy that are either continuously resupplied by the sun or tap inexhaustible resources, such as wind, solar, biomass, hydropower, and geothermal energy.

Solar heating - Various technologies for using the sun's energy to heat water and living spaces.

Solar thermal electric - A technology for generating electricity from the sun's heat.
Watt - Watts are used to measure the total quantity of electricity. One watt is the power developed by an electric current of 1 ampere across a potential of 1 volt.

1 kilowatt $(\mathrm{kW})=1000$ watts

1 megawatt $(\mathrm{MW})=1000$ kilowatts $=$ 1 million watts

1 gigawatt $(\mathrm{GW})=1000$ megawatts $=$ 1 billion watts

Both $\mathrm{kW}$ and MW are used to describe the maximum output of an electric generator at a particular moment. Power plant capacities are usually quoted as "rated capacity," measured in $\mathrm{kW}$ or MW, which is the greatest amount of power that the plant can deliver at a given instant. The amount of electricity generated or used during a period of time is typically expressed in kilowatt-hours (kWh).

Wind farm - Another name for a wind power plant, so-called because the turbines are usually spread out over a relatively large area of land.

Wind power plant - A group of wind turbines connected to a common electricity grid. 
NOTICE: This report was prepared as an account of work sponsored by an agency of the United States government. Neither the United States government nor any agency thereof, nor any of their employees, makes any warranty, express or implied, or assumes any legal liability or responsebility for the accuracy, completeness, or usefulness of any information, apparatus, product, or process disclosed, or represents that its use would not infringe privately owned rights. Reference herein to any specific commercial product, process, or service by trade name, trademark, manufacturer, or otherwise does not necessarily constitute or imply its endorsement, recommendation, or favoring by the United States government or any agency thereof. The views and opinions of authors expressed herein do not necessarily state or reflect those of the United States government or any agency thereof.

Printed in the United States of America

Available to DOE and DOE contractors from: Office of Scientific and Technical Information (OSTI) P.O. Box 62, Oak Ridge, TN 37831 (615) 576-8401

Available to the public from: National Technical Information Service (NTIS) U.S. Department of Commerce 5285 Port Royal Road, Springfield, VA 22161 (703) 487-4650

Information pertaining to the pricing codes can be found in the current issue of the following publications which are generally available in most libraries: Government Reports Announcements and Index (GRA and I); Scientific and Technical Abstract Reports (STAR); and publication NTIS-PR-360 available from NTIS at the above address.

Produced for the U.S. Department of Energy

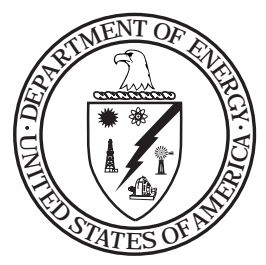

1000 Independence Avenue, SW Washington, DC 20585

by the National Renewable Energy Laboratory a DOE national laboratory

DOE/GO-10097-261

DE96000543

September 1997

Printed with renewable-source ink on paper containing at least $50 \%$ wastepaper, including $20 \%$ postconsumer waste 